\title{
Influence of Food and Beverage Companies on Retailer Marketing Strategies and Consumer Behavior
}

\author{
Amelie A. Hecht ${ }^{1, *}$, Crystal L. Perez ${ }^{1}$, Michele Polascek ${ }^{2}$, Anne N. Thorndike ${ }^{3}$ (i), \\ Rebecca L. Franckle ${ }^{4}$ and Alyssa J. Moran ${ }^{1}$ \\ 1 Department of Health Policy and Management, Johns Hopkins Bloomberg School of Public Health, \\ Baltimore, MD 21205, USA; CPerez20@jhu.edu (C.L.P.); AMoran10@jhu.edu (A.J.M.) \\ 2 Westbrook College of Health Professions, University of New England, Portland, ME 04103, USA; \\ mpolacsek@une.edu \\ 3 Department of Medicine, Massachusetts General Hospital and Harvard Medical School, Boston, MA 02114, \\ USA; athorndike@mgh.harvard.edu \\ 4 Program in Global Public Health and the Common Good, Department of Biology, Boston College, \\ Chestnut Hill, MA 02467, USA; franckle@bc.edu \\ * Correspondence: AHecht3@jhu.edu
}

Received: 11 September 2020; Accepted: 3 October 2020; Published: 10 October 2020

\begin{abstract}
The retail food environment plays an important role in shaping dietary habits that contribute to obesity and other chronic diseases. Food and beverage manufacturers use trade promotion-incentives paid to retailers-to influence how products are placed, priced, and promoted in stores. This review aims to: (1) catalogue trade promotion practices that manufacturers use to influence retailer marketing strategies, and (2) describe how these retailer marketing strategies affect consumer purchasing behavior and attitudes. Researchers searched five databases, Academic Search Ultimate, Business Source Ultimate, PsycINFO, PubMed, and Web of Science, to identify literature from industry and academic sources published in English through November 2019. Twenty articles describing manufacturer trade promotion practices were synthesized and provided insight into four types of trade promotion practices: category management, slotting allowances, price discounts, and cooperative advertising. Fifty-four articles describing the impact of retailer marketing on consumers were synthesized and graded for quality of evidence. While comparison across studies is challenging, findings suggest that retailer marketing strategies, such as price promotions and prominent placement, lead to increased sales. Results can guide efforts by policymakers, public health practitioners, and food retailers to design retail environments that improve healthy eating while maintaining retailer financial interests. Additional research should measure the impact of retailer marketing strategies on consumer diet quality and retailer outcomes (e.g., return-on-investment).
\end{abstract}

Keywords: trade promotion; price; promotion; placement; food and beverage; food retailer; grocery; consumer behavior; marketing; chronic disease; choice architecture

\section{Introduction}

The retail food environment plays a critical role in shaping dietary habits and is an important setting for interventions to improve diet quality and prevent diet-related chronic diseases, including diabetes, obesity, and cardiovascular disease [1]. Evidence suggests that marketing of unhealthy foods and beverages may be more common and effective at driving sales compared to marketing of healthy foods and beverages [2-9]. Low-income and racial and ethnic minority populations are disproportionately targeted by unhealthy food marketing, which may exacerbate disparities in diet quality and diet-related chronic disease [10]. For example, advertisements for low-cost, high-calorie, and low-nutrition foods 
and beverages appear more often in media watched by African Americans [11]; and retailers increase marketing of sugar-sweetened beverages when Supplemental Nutrition Assistance Program (SNAP) benefits are issued each month [12].

Retail food stores, which include both online and brick-and-mortar retailers (see Appendix A for a list of retail formats), are the primary source of food for many populations in both developed and developing economies [13]. In the US, consumers acquire the majority of their calories from supermarkets and superstores [14]. Considering that consumers make an estimated three-quarters of their purchasing decisions while shopping [15], in-store marketing techniques may play an important role in shaping purchase attitudes and decisions $[9,16]$.

Food and beverage manufacturers use trade promotion practices (TPP), or incentives to retailers, to shape in-store marketing [17]. This paper focuses on how TPP influence three out of the "4Ps" of marketing: price, place (both the channels through which products are sold and where products are placed in stores), and promotion (efforts to engage consumers and communicate product features, such as signs) [18]. The fourth " $\mathrm{P}$ " of marketing, "product," is less frequently shaped by TPP, but rather by manufacturers in-house, through efforts such as packaging and product formulation. Similarly, TPP more commonly shapes where items are placed in stores and on shelves (i.e., product placement) rather than the channels through which products are sold. Food and beverage manufacturers allocate about $\$ 1$ trillion annually to TPP-between 50 and $70 \%$ of their marketing budgets and nearly $20 \%$ of their total revenue $[17,19]$.

There is growing interest among policymakers, researchers, advocates, and retailers in creating policies and corporate practices that promote healthy food retail. To inform efforts to improve the food retail environment, it is important to understand (1) the types of TPP currently used by food and beverage manufacturers to influence retailer marketing strategies, and (2) how retailer marketing strategies, in turn, affect consumers. The first part of this research question-which types of TPP are used to influence retailers-is understudied, particularly in the public health literature. A 2016 investigative report commissioned by the Center for Science in the Public Interest, which describes TPP but did not use a systematic approach to gather data or survey the literature, served as a launching point for this aim [17].

The second part of this research question-how retailer marketing strategies impact consumers-has been only partially explored in previous reviews. Specifically, three previous reviews have focused on price promotions' impact on consumers; all three concluded that price promotions were associated with consumer behavior $[3,9,20]$. In a 2012 integrative review, Glanz et al. synthesized literature on the impact of price, placement, and promotion on consumer behavior but limited their search to literature focused on brick-and-mortar grocery stores. They found that all three marketing strategies were associated with increased product liking and purchasing, with some variation in degree of impact by strategy [21]. This review serves as an update to and expansion of the Glanz et al. review, synthesizing literature since 2011 and including other nontraditional retail settings such as online retailers and convenience stores. This review focuses on identifying, where possible, whether and how outcomes differ when healthy versus unhealthy products are marketed. Findings from this study can inform efforts by advocates, policymakers, public health practitioners, and food retailers to design food retail environments that promote healthy eating while maintaining retailer financial interests. This study will also identify gaps in the literature and provide directions for future research.

\section{Methods}

Two research questions were identified: (1) how do food and beverage manufacturers use TPP to influence retailer marketing strategies; and (2) how do retailer marketing strategies impact consumer purchasing behavior and attitudes? Searches were conducted for peer-reviewed and grey literature (e.g., conference abstracts and proceedings, reports, dissertations) in English. To identify publications from diverse disciplines including public health, business, economics, marketing, and social sciences, the following databases were searched: Academic Search Ultimate, Business Source Ultimate, PsycINFO, 
PubMed, and Web of Science. Search terms for each research question were developed by the study authors in consultation with industry and academic experts and a research librarian (Appendix B). The selection and analysis of the results were carried out under the Preferred Reporting Items for Systematic Reviews and Meta-Analyses (PRISMA) guidelines [22].

\subsection{Research Question 1: Search Strategy and Inclusion Criteria}

To answer the first research question, a narrative review was conducted to identify and catalogue types of trade promotion practices used by food and beverage manufacturers to influence retailer marketing strategies (Figure 1). Articles published through November 2019 were included. Article titles and abstracts were independently screened by two authors ( $\mathrm{AH}$ and $\mathrm{CP}$ ) for inclusion. Full-text review was completed by the first author $(\mathrm{AH})$. Any questions about study inclusion were resolved through discussion with the second author (CP).
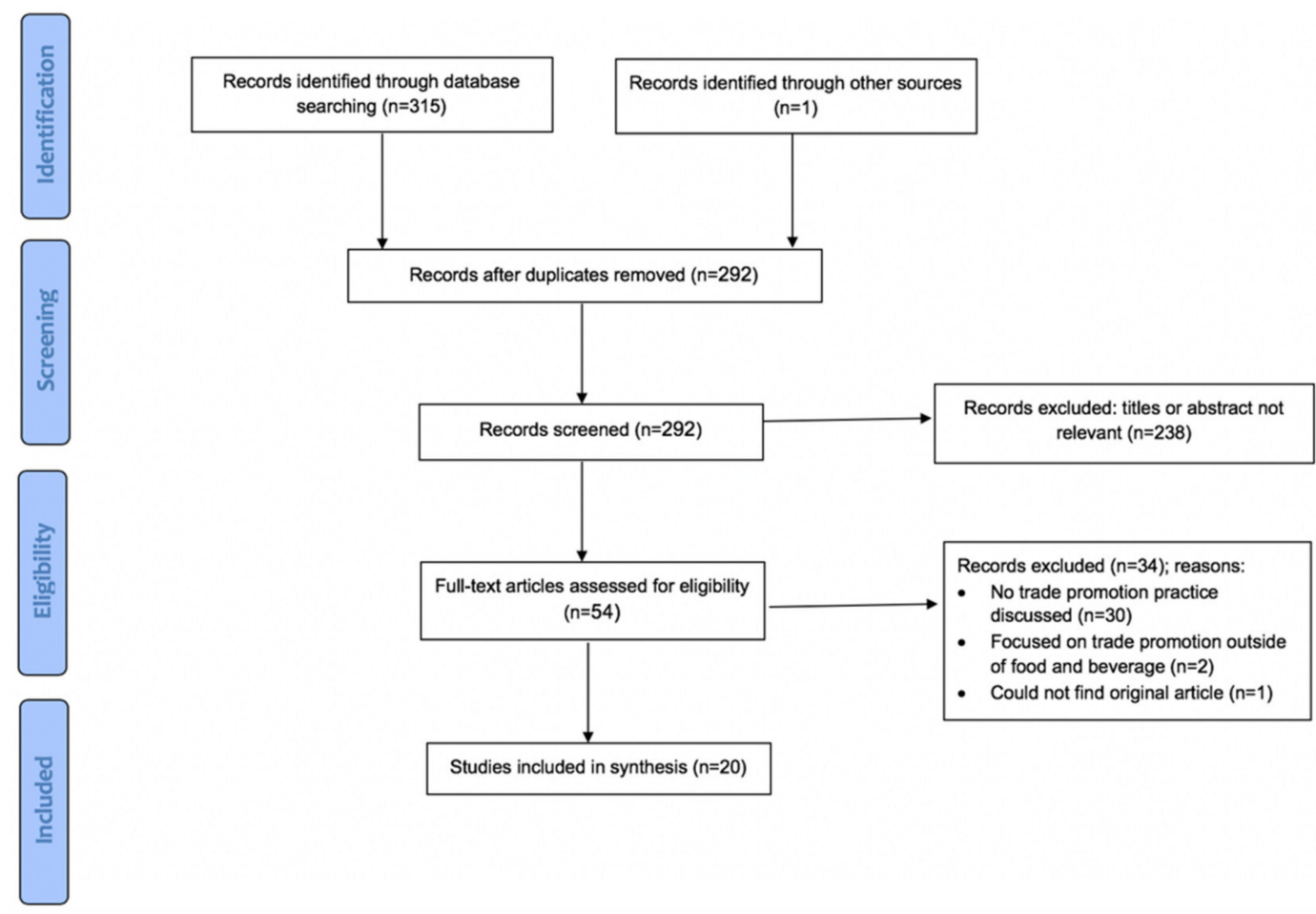

Figure 1. Preferred Reporting Items for Systematic Reviews and Meta-Analyses (PRISMA) Diagram for Research Question 1.

\subsection{Research Question 2: Search Strategy and Inclusion Criteria}

To answer the second research question, a systematic review was conducted to understand the impact of retailer marketing strategies on consumer behavior and attitudes (Figure 2). Inclusion criteria were that the article must (1) be published between January 2011 and November 2019 (to capture studies published since the Glanz et al. review) and (2) measure the impact of retailer marketing strategies influenced by TPP on consumer purchasing behavior or attitudes. Studies were excluded if they assessed (1) an investigator-driven healthy retail intervention (review by Karpyn et al., forthcoming); (2) retailer or manufacturer practices unrelated to TPP (e.g., product labeling); (3) restaurants, vending machines, cafeterias, or schools, or (4) were not original research (e.g., literature reviews). The excluded literature reviews were incorporated into the background and discussion section of this review. Two authors (AH and $\mathrm{CP}$ ) independently reviewed titles, abstracts, and full texts for inclusion and met to reconcile differences. Reference lists of included articles were also scanned, and relevant articles included. 

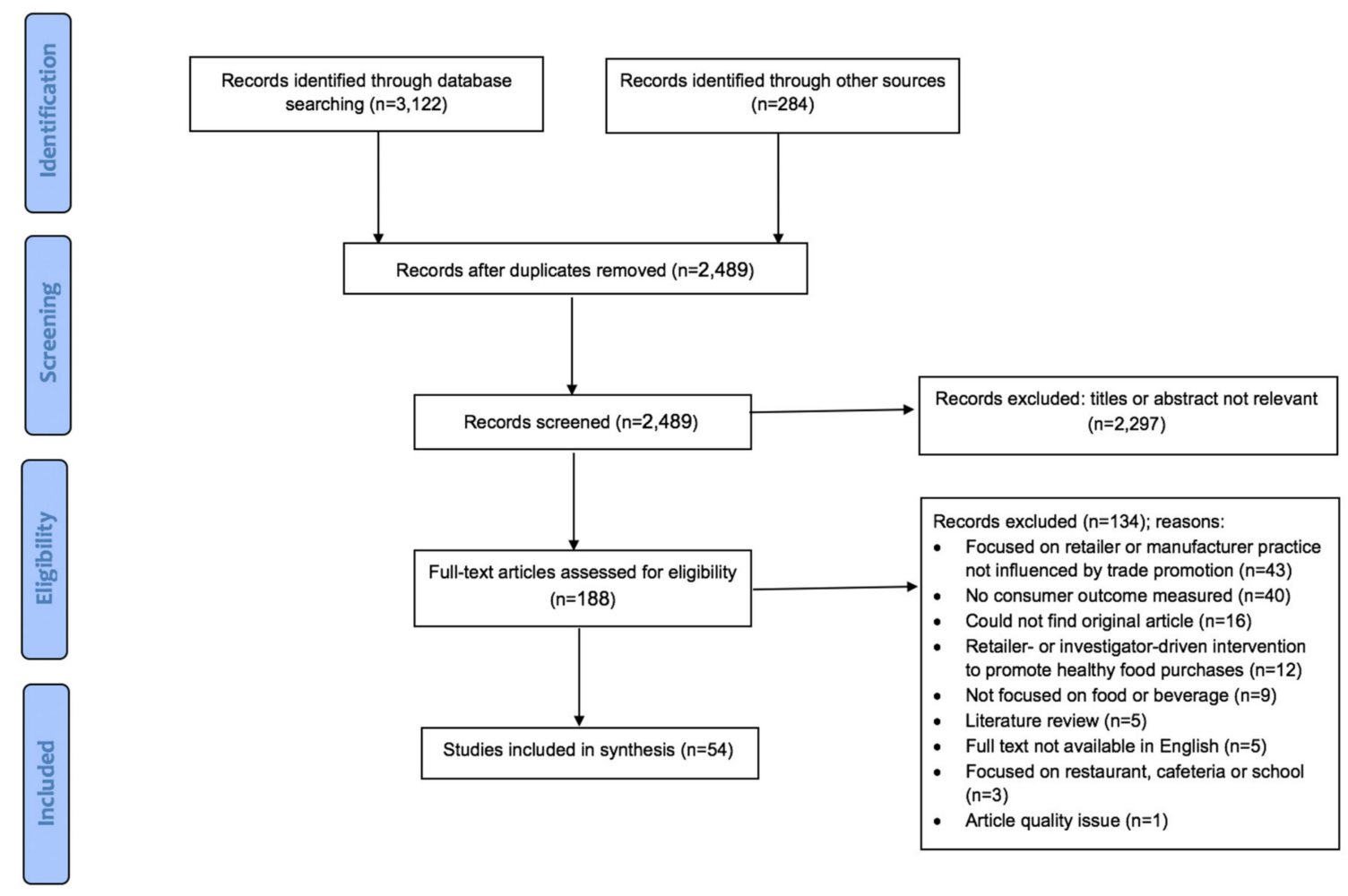

Figure 2. PRISMA Diagram for Research Question 2.

\subsection{Quality of Studies}

The quality of included studies for the second research question was assessed using the Newcastle-Ottawa quality assessment scale, adapted for cross-sectional studies [23] (Appendix C). The Newcastle-Ottawa scale assigns studies composite quality scores by awarding a certain number of stars out of a total of nine possible stars. Similar to an approach used by Bennett et al., amendments were made to the scale; for articles using aggregate sales data, a "not applicable" option was allowed for categories of "non-respondents" and "controlling for confounding variables" [3]. The denominator (total number of possible stars) was reduced appropriately. Two authors (AH and CP) independently graded the included studies and met to reconcile differences. As described by Takehashi and Hashizume [24], studies that earned fewer than a third of the possible stars were classified as low-quality studies.

\section{Results}

\subsection{Narrative Review of Trade Promotion Practices}

Twenty articles were identified that described TPP used by manufacturers to influence retailer marketing strategies [25-44]. Of these, 13 articles were published in the peer-reviewed literature or through conference proceedings and seven articles were published in trade publications. Of peer-reviewed publications, two were in public health or public policy journals and the remainder were in journals focused on retail, economics, or marketing. Thirteen articles focused on the US, six focused on other countries, including Brazil, the United Kingdom (UK), New Zealand, Sweden, Finland, Italy, and Portugal, and one used a global perspective.

Results indicate that manufacturers use four types of TPP to shape retailer marketing strategies: (1) category management, (2) slotting allowances, (3) price discounts, and (4) cooperative advertising (Table 1). These terms may differ across retailers, manufacturers, and countries; for example, in Europe, slotting allowances are also referred to as listing charges [25]. Certain types of TPP may be used more often for some product categories and in some retail formats. For example, slotting allowances are more often used in highly concentrated, processed product categories such as beverages, snacks, 
and candy [32]. In smaller stores, such as convenience and corner stores, more informal incentive-based agreements between suppliers and retailers are common [36].

Table 1. Definitions of trade promotion practices.

\begin{tabular}{cc}
\hline Trade Promotion Practice $(n)$ & Definition \\
\hline Category management (11) & $\begin{array}{c}\text { Collaboration between retailers and manufacturers to make decisions regarding } \\
\text { product assortment, supply, pricing, and promotion for entire categories }\end{array}$ \\
\hline Slotting allowances (7) & $\begin{array}{c}\text { Lump-sum fees paid by manufacturers to retailers in exchange for access to the } \\
\text { consumer market (e.g., shelf space, prominent placement) }\end{array}$ \\
\hline Price discounts (4) & $\begin{array}{c}\text { Fixed discounts (merchandise is sold at a set discount for a specified period) or } \\
\text { performance-based discounts (discounts are tied to a measure of performance } \\
\text { such as units sold or displayed) }\end{array}$ \\
\hline Cooperative advertising (1) & Cost-sharing between retailers and manufacturers to create and distribute \\
promotional materials
\end{tabular}

Note: some articles discussed multiple trade promotion practices, so ns sum to greater than the total number of included articles.

\subsubsection{Category Management}

Eleven articles focused on category management [27,28,31,34,35,37-39,41,43,44]. Category management is the collaboration between manufacturers and retailers to make decisions regarding product assortment, space allocation, pricing, and in-store promotion for entire product categories. Categories (e.g., ice cream, yogurt) are treated as strategic business units to ensure maximum efficiency and boost sales for the whole category, rather than for individual brands [27]. Category management typically uses a shopper-centric and research-based approach to promote consumer satisfaction and loyalty $[39,41,44]$.

A leading manufacturer in a category often serves as the "category captain," overseeing category management and customizing plans on a store-by-store basis. Such an arrangement is often considered beneficial for both retailers and manufacturers: it allows retailers to concentrate on other aspects of their business, and manufacturers to focus on increasing category market share and profitability [28]. While some retailers have safeguards in place to ensure category captains are not unfairly advantaged, critics contend that because category captains have influence over which brands and products within a category are stocked and promoted, category captains may be able to exclude competitors $[28,43]$.

\subsubsection{Slotting Allowances}

Seven articles focused on slotting allowances, or lump-sum fees paid by manufacturers to retailers in exchange for access to the consumer market (i.e., shelf space) $[25,29,32,33,36,40,42]$. These include slotting fees to introduce a new product onto shelves, pay-to-stay fees to maintain shelf position, floor fees to make sales presentations and offer in-store samples, and display fees, which may cover premium placement, display materials (e.g., wire racks, prefabricated displays), and promotional signage. Theoretical explanations for why slotting allowances have become widely used include a market power explanation (i.e., slotting allowances reflect growing power among retailers who control access to the market) and an efficient market explanation (i.e., slotting allowances enable efficient allocation of scarce shelf space) [25]. According to the efficient market rationale, slotting allowances help retailers defray the costs and risks associated with new product introductions in light of an estimated $70 \%$ failure rate for new products [45]. Evidence suggests that slotting allowances in the US alone total between $\$ 6$ billion and $\$ 18$ billion per year $[25,46]$. Nationwide introduction of a new product in the US can cost up to \$1-2 million in slotting fees [45]. In countries with more independent retailers, slotting allowances are less common. 


\subsubsection{Price Discounts}

Four articles discussed price discounts that manufacturers provide to retailers to incentivize retailers to stock, display, or provide promotional discounts for their products $[26,33,36,47]$. Manufacturer discounts may be fixed or performance-based [47]. Fixed discounts are price reductions offered to the retailer on a per unit or per case basis, often at the time of billing, for a limited period of time. Performance-based discounts are tied to a measure of retailer performance such as number of units sold, displayed, or offered on price promotion. Discounts may be passed on to the consumer in the form of temporary price reductions (TPR) or coupons, affecting final sale prices [33,47]. Manufacturers may also provide retailers products for free to encourage retailers to stock new products or provide customer discounts, giveaways, or in-store samples [26,36].

\subsubsection{Cooperative Advertising}

One article focused on cooperative advertising. Cooperative advertising is the collaboration between manufacturers and retailers to create and distribute local promotional materials such as newspaper inserts or direct mail flyers [42]. A cooperative advertising agreement may be initiated by either a retailer or manufacturer. Typically, the manufacturer will design the promotional materials, providing product images and templates, and the manufacturer and retailer will share the cost of printing and distribution.

\subsection{Literature Review of Impacts of Retailer Marketing Strategies on Consumers}

Fifty-four articles that describe the impact of retailer marketing strategies on consumer behavior or attitudes were identified (Table 2$)$. These included peer-reviewed literature $(n=44)$, dissertations $(n=4)$, conference proceedings $(n=3)$, reports from government or industry $(n=2)$, and trade publications $(n=1)$. Studies occurred in the US $(n=17)$, UK $(n=11)$, other European countries $(n=8)$, Asian and Middle Eastern countries $(n=8)$, Australia or New Zealand $(n=6)$, Canada $(n=1)$, and Egypt $(n=1)$; two articles did not specify location. Articles focused on a range of retail formats, including supermarket/grocery stores $(n=43)$; convenience/corner stores $(n=9)$; online retailers $(n=4)$; dollar stores $(n=1)$; other (e.g., organic markets, liquor stores, pharmacies, $n=9$ ); and four articles did not specify the retail format assessed. Ten articles evaluated multiple retail formats. Data sources used varied widely; scanner or panel data was the most commonly used data source (e.g., Kantar Worldpanel data) $(n=26)$, followed by customer survey $(n=21)$, direct observation $(n=9)$, customer interviews or focus groups $(n=8)$, marketing data from the manufacturer or retailer $(n=5)$, retailer loyalty card data $(n=4)$, and other data sources (e.g., customer diaries, eye scanner, store audits, bag checks, $n=6)$; one article did not specify the data source used. Nearly one third $(n=17)$ used multiple data sources. No articles declared conflicts of interest.

TPP influence three categories of retailer marketing strategies: how products are priced, placed, and promoted. Results below are organized according to these three domains. Notably, comparison across studies is challenging given they focus on different products, use different study designs, and employ different outcome measures. The two final sections of the results describe findings from studies that compare outcomes across two or more retailer marketing strategies and compare the impact of marketing of healthy versus unhealthy products.

\subsubsection{Pricing}

Retailers employ a variety of price promotion strategies, including coupons, bundle deals (e.g., buy-one-get-one, 2-for-1), and TPR (also called rollbacks). In the US and the UK, an estimated 40\% and $34 \%$ of all purchases are price promoted, respectively [6,48]. Estimates indicate that between 24\% [49] and $67 \%$ [4] of unhealthy foods and beverages are purchased while price promoted, though prevalence of promotions differ across retailer formats and neighborhood [4]. A review of price promotions among Scottish retailers found that TPR are the most prevalent form of price promotion, accounting for $74 \%$ 
of promotions, followed by bundle deals, which represent $23 \%$ of promotions [9]. Price promotions are offered more frequently for unhealthy compared to healthy products $[2,3,5,7-9,20,50,51]$.

Thirty-two articles focused on price promotions. Eight presented results separately for coupons, seven presented results separately for TPR, and the remainder did not specify the type of price promotion assessed or assessed multiple types of price promotion and did not present results separately.

\section{Coupons}

Coupons may be distributed by retailers or manufacturers. In 2017, 302 billion coupons for consumer packaged goods were distributed in the US [52]. Six studies evaluated coupons and reported coupons were associated with increases in overall purchase volume, impulse purchase volume, brand choice, and product trialing (first-time purchase), but not brand loyalty [53-58]. Two studies assessed customized coupons, which target consumer groups based on demographic characteristics or past shopping behavior, and found they were associated with increased purchasing of targeted products $[54,56]$. Coupons in some product categories may be more impactful than others: one study found that coupons led to greater product trialing when promoting leading brands and categories that were popular, easy to store, had fewer products in the category (easier for customers to process less options), and were frequently on sale [55]. Another study found that while customized coupons led to increased purchases for both healthy and unhealthy products, they were more effective for unhealthy products [54].

\section{Temporary Price Reductions}

All eight studies that evaluated TPR detected associations with one or more consumer shopping behaviors, including purchase volume, impulse purchase volume, brand choice, and brand market share [58-65]. TPR may have a stronger impact on some outcomes compared to others: one study that assessed wine purchases in the UK found that TPR strongly influenced brand selection, somewhat influenced purchase volume, but did not influence purchase initiation [61].

Three articles assessed the impact of TPR in online retail [63-65]. Two out of three studies found that online price promotions were associated with increased purchases $[63,64]$; the third found no association [65]. One of the two studies that detected an association reported that because online purchases were delivered, barriers to stockpiling were eliminated, resulting in increased purchase volume compared to in traditional brick-and-mortar retail outlets [64]. The other reported that when a retailer with both online and brick-and-mortar retail outlets offered price promotions online, online sales increased, but sales in the brick-and-mortar stores decreased [63]. That study also found that high frequency of online promotions led to diminished effects over time [63].

\section{Other Price Promotions}

Thirteen articles on price promotions did not specify the type of price promotion studied or examined several types of price promotions together $[6,8,50,66-75]$. Many studies using panel data were unable to distinguish between types of price promotion used by customers. All studies identified positive associations between price promotions and one or more outcomes, including purchase volume, stockpiling purchase volume, purchase initiation, product trialing, and store choice. Within some studies, however, price promotions were positively associated with some outcomes and not others. For example, one study assessing Japanese market trends over time found that manufacturer expenditure on sales promotion was associated with an increase in total purchase volume but a decrease in manufacturer profits [66]. Another study found that price promotions led to short-term sales increases, but in more than half of cases, did not increase category revenue due to brand-switching (substitution) effects within the category [70].

Quantitative estimates on the impact of price promotions are difficult to compare because researchers used different outcome measures. Three studies, all using data from the Kantar Worldpanel, illustrate this challenge $[6,8,69]$. Nakamura et al. estimated that a $1 \%$ increase in price discount led to a 
sales uplift of $1.44 \%$ within a given category [6]. Smithson et al. found that approximately one-fifth of foods and beverages bought on price promotion were purchased in addition to what would be expected absent a price promotion, leading to an overall increase in food and drink purchase volume [8]. Revoredo-Giha et al. found that the presence of a price promotion increased spending between $2 \%$ and $10 \%$, depending on the product category [69].

The effect of price promotions may differ across product categories and consumer characteristics. For example, one study found that while, price promotions did not, on average, affect beef sales, they did influence sales for certain cuts of meat and consumer groups (e.g., young families versus older adults) [68]. Another study found that price promotions were associated with increased soda sales across all levels of consumer education and retail formats, but the effect was weaker in neighborhoods with a higher proportion of residents with at least a post-secondary certificate or diploma [71].

Three studies compared differences in the impact of price promotion on healthy and unhealthy products $[67,69,74]$. Two of these studies found that purchase volume increased as price decreased for unhealthy foods but not for healthy foods $[67,74]$. Another, however, found that price promotions led to increases in total spending and spending by category for both healthy and unhealthy foods, though the effect was greater for less healthy foods [69]. Specifically, they found greater increases in spending for unhealthy categories such as confectionery $(10 \%)$ and beverages $(9 \%)$ and smaller increases for healthier categories such as fruits and vegetables (5\%), grains $(3 \%)$, and dairy $(2 \%)$.

\section{Perceived Importance of Price Promotions}

Eight articles assessed consumer perceptions regarding the importance of price promotions in shaping their purchasing decisions [67,73,76-82]. Though the populations and contexts assessed varied across articles, all studies found that shoppers considered price promotions to be an important factor influencing their shopping behavior. Three of these studies assessed perceived importance of price promotions within specific cultural and religious contexts. In one study, Egyptian Muslim shoppers reported that TPR and bundled deals led them to engage in more stockpiling and spending, but other discount promotions considered not compliant with Shari'ah law, such as sweepstake draws and scratch-and-win promotions, did not shape their behavior [79]. In a study of Pakistani Muslim shoppers, participants reported that their intentions to purchase Halal products were shaped by price promotions [80]. Through interviews with "ethnic" shoppers in the UK, a final study found that participants reported diverse responses to price promotions, ranging from responsive to hostile, depending on the perceived "net worth" of the promotion [81].

\subsubsection{Placement}

Sixteen studies focused on how products were placed within stores, measuring visual attention, purchase volume, or spending as the primary outcomes $[15,46,58,62,83-94]$. Through slotting allowances and category management, manufacturers are able to secure placement in premium store locations, including on the endcap (i.e., end-of-aisle displays free from direct aisle-based competition), in the checkout aisle, and on freestanding displays. In 2012, an estimated $60 \%$ of products in stores were cross-promoted, meaning they are were displayed in secondary locations away from their "home" aisle [15]. Displays may be located anywhere in the store: approximately $42 \%$ of displays are located on the endcap, $28 \%$ in the aisle, $23 \%$ on the perimeter of the store, and $7 \%$ at the front of the store [15]. In an evaluation measuring shoppers' visual attention, $13 \%$ of all eye-fixations were drawn to in-store displays; of these, $44 \%$ were to endcaps, $34 \%$ to floor stands, $12 \%$ to in-line displays (i.e., gondola, or freestanding wire or metal shelving), and $10 \%$ to power wings (i.e., sidekick displays, or cardboard displays that attach to shelving) [15].

\section{Endcaps}

Five studies focused on placement in endcaps; all found significant positive effects on purchasing $[46,83,85-87]$. In a study of UK stores, endcap displays led to increased purchase volume for 
beer by $23.2 \%$, for wine by $33.6 \%$, for spirits by $46.1 \%$, and for carbonated drinks by $51.7 \%$; sales uplift was even greater for tea and coffee [85]. Two studies found that endcaps located at the rear of the store are more impactful than those at the front of the store [47,91]. In an experimental study in Australian grocery stores, placement of unhealthy products on rear endcap displays generated a $416 \%$ uplift in sales, while placement on front endcap displays generated a $346 \%$ uplift in sales [46]. Findings also suggest that endcaps are most impactful when located away from in-store sampling [87] and in stores without middle, perpendicular aisles [86].

\section{Shelf Placement and Space}

Category management and display fees can also affect where categories are placed within a store, and where individual products are placed on shelves (e.g., at eye-level for adult shoppers). Three experimental studies suggest that placement at the front of the store, in central aisles, at eye-level, and away from other popular categories can have positive effects on sales $[88,91,92]$. In one study, moving fruits and vegetables to a prominent location at the front of a grocery store led to an increase in sales volume and spending on fruits and vegetables [92]. In another, placement of dairy products in a central aisle was associated with increased product sales and purchase incidence, while placement next to popular categories had an "attention stealing" affect, leading to decreased sales [88]. In a laboratory-based study of college students, junk food items placed at eye-level received more visual attention than those on higher or lower shelves [91]. However, an observational study in New York City bodegas found no association between unhealthy beverage purchases and the placement of healthy products in prominent locations (i.e., water at eye-level and produce in at the front of the store) [89].

Total amount of dedicated shelf and display space (measured in feet) was associated with increased sales in two studies [84,90]. In one study, Minneapolis stores with more shelf space dedicated to fruits and vegetables had healthier purchases (i.e., more fruits and vegetables, more whole grains, and higher healthy eating index scores) [84]. Similarly, in a study of Hispanic shoppers in San Diego tiendas, each additional square foot of display space for fruits and vegetables was associated with a $\$ 0.02$ increase in weekly amount spent on fruits and vegetables [90].

\section{Other Placement Strategies}

Four additional studies evaluated the impact of placement but did not specify how or where evaluated products were displayed $[58,62,93,94]$. All four studies found that presence of displays was positively associated with impulse purchase volume, spending, or brand choice. One of these studies was an industry report that assessed a multifaceted marketing campaign, however, and it is unclear what proportion of the sales uplift was attributed to placement [93].

\subsubsection{Promotion}

Sixteen articles focused on promotion [53,73,76,80,82,84,87,89,90,95-101]. Manufacturers use cooperative advertising and display fees to secure promotional signage, in-store sampling (i.e., taste tests), loudspeaker announcements, games, and other giveaways.

\section{Signs}

All three studies that measured the relationship between signs on shelf facings (called shelf-talkers or aisle violators) and purchase behavior focused on promoting healthy products; none detected a significant association $[84,89,90]$. In tiendas in San Diego, the number of signs promoting fruits and vegetables was not associated with fruit and vegetable purchases among Hispanic consumers [90]. In Minnesota stores, healthy advertising inside stores was not associated with purchasing, and, in fact, healthy advertising outside stores was associated with less healthy purchases [84]. In New York City bodegas, neither signs advertising water nor signs advertising sugar-sweetened beverages were associated with sugar-sweetened beverage purchases [89]. 
One study assessed "feature advertising" in two competing grocery stores, but did not describe components of "feature advertising" [73]. This study found that feature advertising led customers to choose to shop at the store with featured advertising over another store.

In-Store Sampling

In-store sampling was found to be associated with greater brand loyalty and purchase volume in three studies $[53,87,99]$. Several factors may moderate the impact of in-store sampling on purchases: studies suggest that benefits are maximized when the product being offered on sample matches the product displayed on the closest endcap [87,99]. One study also found a sales increase when in-store samples were offered close to the weekend compared to earlier in the week, when store personnel were present to offer the sample (24.3\% increase compared to without store personnel present), when there was a sign promoting the product ( $90.8 \%$ increase compared to no sign), and when a commercial for the product is played on an in-store TV (36.3\% increase compared to no commercial) [99].

\section{Games, Giveaways and Limited-Time Offers}

Findings on the impact of games, giveaways, and limited-time offers differed across studies $[53,82,100]$. In one study, customers reported that in-store games and lotteries led to greater customer loyalty and stronger relationships with promoted brands [53]. In another study, giveaways of collectible items increased the probability of brand choice and category purchase incidence, particularly when paired with a price discount, but did not change the purchase volume decision [100]. In a final study, both limited-time and membership deals were found to increase purchase incidence in an organic market [82].

\section{Perceived Importance of Promotions}

Seven articles assessed consumer perceptions regarding the importance of promotional activities in shaping their purchasing decisions $[76,80,95-98,101]$. Studies investigated different types of promotions and used different methods to assess customer perceptions, and found varying levels of perceived importance. Five studies found that consumers reported high levels of perceived importance of marketing on their attitudes toward purchasing [80,96-98,101]. Two studies, however, found promotional offers to be less persuasive: in a survey of Australian shoppers, $41 \%$ said they were influenced by promotional offers, but, in focus groups and interviews, many said that while promotional offers engaged them initially, trust and emotional connection to the brand was the primary driver of their purchase decisions [95]. In a survey of Vietnamese urban shoppers, participants described merchandise display and promotion as the least important factor from a list of seven factors influencing impulse purchase behavior [76].

\subsubsection{Comparison of Marketing Healthy versus Unhealthy Products}

As previously described, a small number of studies compared marketing of healthy versus unhealthy products $[54,67,69,74,84,89,90]$. Of these, four focused on price, three on placement, and three on promotion. Half of price-focused studies found that price promotions led to increased purchasing of unhealthy but not healthy products, $[67,74]$ whereas the other half of studies found that while the effect was stronger for unhealthy products, price promotions led to increased purchasing of both healthy and unhealthy products. One of the three studies focused on placement found no association between prominent placement of healthy products and purchasing [89]. The other two studies, however, found that stores with more shelf and display space dedicated to fruits and vegetables had healthier sales $[84,90]$. Notably, both of these studies were cross-sectional and thus were unable to determine causality. Finally, none of the three studies focused on signs promoting healthy products detected a relationship with purchasing $[84,89,90]$. 


\subsubsection{Comparison across Marketing Strategies}

A small number of articles directly compared one retailer marketing strategy to another. Four of these asked participants to rank factors that shape their purchasing; in all four, participants reported that price promotions were the most or one of the most influential factors shaping their attitudes toward purchasing. Vietnamese shoppers reported that price promotions influenced their spontaneous purchase tendencies more than displays [76]. Taiwanese organic market shoppers reported that discounts and free giveaways impacted their shopping behavior more than membership or limited-time offers [82]. Two other studies focused on Muslim shoppers: in one [80], shoppers reported being equally influenced by Halal marketing promotions and pricing, while in the other [79], shoppers reported price discounts influenced their purchase intention more than giveaways, games, and in-store samples.

One study compared different types of price promotions, finding that sensitivity to coupons was greater than sensitivity to TPR [58]. The remaining studies quantitatively compared price promotions to either promotion or placement; results largely indicated that price promotions are more impactful than other types of marketing strategies $[53,59,73,85]$. Specifically, one study found that price was a stronger driver of stockpiling purchases than feature and display promotion [73]. Another found that a 20\% TPR increased fair trade coffee sales more than providing information or a moral appeal [59]. Another study found that the effect size for endcap placement was equivalent to a price decrease for alcohol categories of between $4 \%$ and $9 \%$ per volume, and a price decrease for non-alcohol categories of between $22 \%$ and $62 \%$ per volume [85]. One study, however, found that price promotion and in-store sampling produced different benefits: in-store sampling helped nurture consumer loyalty more than coupons, but coupons resulted in more purchases [53].

\subsubsection{Quality of Evidence Grading}

On average, included studies received $65 \%$ of total possible stars (Appendix D). Only three of the 54 studies included in this review were of low-quality, having earned less than a third of all possible stars. The two categories in which studies most often earned zero stars were sample size $(n=27)$ and non-respondents $(n=28)$. Nearly half of the included articles omitted sample size calculations or justification; this was particularly common among studies using questionnaires or published in non-peer-reviewed sources. Only one study compared respondents and non-respondents or reported their response rate, though for 25 articles, this information was considered not applicable due to use of panel data. More than half of all studies earned the maximum number of stars in the assessment of outcome category by linking records or using an independent blind assessment to determine the outcome. 
Table 2. Study design, marketing strategy, retailer format, country, study duration, data source, objectives, outcomes, and key findings for studies included in research Question $2(n=54)$.

\begin{tabular}{|c|c|c|c|c|c|c|c|c|}
\hline Reference & $\begin{array}{l}\text { Marketing } \\
\text { Strategy }\end{array}$ & Retail Format & Country & Study Duration & Data Source & Objective & Outcome & Key Findings \\
\hline $\begin{array}{l}\text { Andorfer, et al. } \\
\text { (2015) [59] }\end{array}$ & Price & $\begin{array}{l}\text { Supermarket/ } \\
\text { grocery store }\end{array}$ & Germany & $\begin{array}{l}5 \text { mo (5 March, } \\
\text { 2012-29 July } \\
\text { 2012) }\end{array}$ & $\begin{array}{l}\text { Scanner/panel } \\
\text { data } \\
\text { Customer } \\
\text { surveys } \\
\text { Direct } \\
\text { observation }\end{array}$ & $\begin{array}{l}\text { To identify how information, } \\
\text { price, and moral considerations } \\
\text { influence consumers' } \\
\text { purchases of fair trade (FT) } \\
\text { coffee products. }\end{array}$ & $\begin{array}{l}\text { Purchase } \\
\text { volume } \\
\text { Purchase } \\
\text { frequency }\end{array}$ & $\begin{array}{l}\text { - A } 20 \% \text { TPR had a positive effect on } \\
\text { coffee purchase volume when } \\
\text { compared to the effects of information } \\
\text { and moral appeal. }\end{array}$ \\
\hline $\begin{array}{l}\text { Arce-Uriza, } \\
\text { et al. (2017) } \\
\text { [65] }\end{array}$ & Price & $\begin{array}{l}\text { Supermarket/ } \\
\text { grocery store } \\
\text { Online retailer }\end{array}$ & Spain & $\begin{array}{c}6 \text { mo (15 May } \\
2007-15 \\
\text { November 2007) }\end{array}$ & $\begin{array}{l}\text { Scanner/panel } \\
\text { data }\end{array}$ & $\begin{array}{l}\text { To evaluate the differential } \\
\text { effect of price promotions on } \\
\text { brand choice when shopping at } \\
\text { a grocery store's online outlet } \\
\text { vs. brick-and-mortar store. }\end{array}$ & Brand choice & $\begin{array}{l}\text { - Price promotions had a positive effect } \\
\text { on purchases made in-person but not } \\
\text { on purchases made online. } \\
\text { - Frequent customers were more } \\
\text { responsive to price promotions than } \\
\text { infrequent customers. }\end{array}$ \\
\hline $\begin{array}{l}\text { Awan, et al. } \\
\text { (2015) [80] }\end{array}$ & $\begin{array}{c}\text { Price } \\
\text { Promotion }\end{array}$ & Not specified & Pakistan & Not specified & $\begin{array}{l}\text { Customer } \\
\text { surveys }\end{array}$ & $\begin{array}{l}\text { To identify which factors affect } \\
\text { consumers' decisions to } \\
\text { purchase Halal food. }\end{array}$ & $\begin{array}{l}\text { Purchase } \\
\text { attitude }\end{array}$ & $\begin{array}{l}\text { - Customers were influenced by Halal } \\
\text { marketing and branding practices (e.g., } \\
\text { sales promotions and celebrity } \\
\text { endorsements). } \\
\text { - Customers were willing to spend } \\
\text { considerable effort and money to } \\
\text { purchase Halal food as a result of } \\
\text { Halal marketing. }\end{array}$ \\
\hline $\begin{array}{l}\text { Aziz, et al. } \\
\text { (2013) [101] }\end{array}$ & Promotion & $\begin{array}{l}\text { Other (shopping } \\
\text { mall) }\end{array}$ & Malaysia & Not specified & $\begin{array}{l}\text { Customer } \\
\text { surveys }\end{array}$ & $\begin{array}{l}\text { To determine the relationships } \\
\text { between factors, including } \\
\text { Halal marketing, and intention } \\
\text { to purchase Halal products. }\end{array}$ & $\begin{array}{l}\text { Purchase } \\
\text { attitude }\end{array}$ & $\begin{array}{l}\text { - Halal marketing promotion was } \\
\text { positively related to purchase } \\
\text { intention. }\end{array}$ \\
\hline $\begin{array}{l}\text { Banks et al. } \\
\text { (2016) [93] }\end{array}$ & Placement & $\begin{array}{l}\text { Convenience } \\
\text { store }\end{array}$ & UK & Not specified & Marketing data & $\begin{array}{l}\text { To describe the impact of } \\
\text { endcap placement and } \\
\text { shelf-ready cases for cookies } \\
\text { sales. }\end{array}$ & $\begin{array}{l}\text { Purchase } \\
\text { volume } \\
\text { Spending } \\
\text { Market share }\end{array}$ & $\begin{array}{l}\text { - Marketing efforts led to an increase } \\
\text { in shoppers' basket size (two-fold } \\
\text { increase), spending ( } £ 3 \text { increase), and } \\
\text { market size (increased to } £ 3.8 \mathrm{bn}) \text { for } \\
\text { cookies. }\end{array}$ \\
\hline $\begin{array}{l}\text { Bogomolova } \\
\text { et al. }(2019) \\
{[50]}\end{array}$ & Price & $\begin{array}{l}\text { Supermarket/ } \\
\text { grocery store }\end{array}$ & Australia & $\begin{array}{l}3 \text { years } \\
(2 \text { February } \\
2012-31 \\
\text { December 2014) }\end{array}$ & $\begin{array}{l}\text { Interviews/focus } \\
\text { groups } \\
\text { Loyalty card } \\
\text { data }\end{array}$ & $\begin{array}{l}\text { To assess reasons for first-time } \\
\text { and impulse purchases }\end{array}$ & $\begin{array}{l}\text { Product trialing } \\
\text { Impulse } \\
\text { purchasing }\end{array}$ & $\begin{array}{l}\text { - The most common factor that } \\
\text { prompted first-time brand purchases } \\
\text { and impulse purchases was an item } \\
\text { being placed on price promotion or } \\
\text { having a special offer. }\end{array}$ \\
\hline
\end{tabular}


Table 2. Cont.

\begin{tabular}{|c|c|c|c|c|c|c|c|c|}
\hline Reference & $\begin{array}{l}\text { Marketing } \\
\text { Strategy }\end{array}$ & Retail Format & Country & Study Duration & Data Source & Objective & Outcome & Key Findings \\
\hline $\begin{array}{l}\text { Breugelmans } \\
\text { and Campo } \\
(2016)[63]\end{array}$ & Price & $\begin{array}{l}\text { Supermarket/ } \\
\text { grocery store } \\
\text { Online retailer }\end{array}$ & UK & $\begin{array}{l}78 \text { weeks (July } \\
\text { 2006-December } \\
\text { 2007) }\end{array}$ & $\begin{array}{l}\text { Scanner/panel } \\
\text { data }\end{array}$ & $\begin{array}{l}\text { To examine the cross-channel } \\
\text { effects of price promotions } \\
\text { (online vs. offline) on category } \\
\text { purchase decisions. }\end{array}$ & $\begin{array}{l}\text { Purchase } \\
\text { incidence } \\
\text { Purchase } \\
\text { volume }\end{array}$ & $\begin{array}{l}\text { - Price promotions had positive effects } \\
\text { on purchasing decisions and degree of } \\
\text { impact varied based on customer } \\
\text { brand loyalty. } \\
\text { - Promotions in one channel decreased } \\
\text { category purchases in the other } \\
\text { channel during the promotion period } \\
\text { (online price promotions had a } \\
\text { stronger impact on offline purchase } \\
\text { decisions than vice versa). } \\
\text { - High promotion frequency had } \\
\text { negative effects on future promotion } \\
\text { effectiveness. }\end{array}$ \\
\hline $\begin{array}{l}\text { Čábelková et } \\
\text { al. (2015) [78] }\end{array}$ & Price & $\begin{array}{l}\text { Supermarket/ } \\
\text { grocery store }\end{array}$ & $\begin{array}{c}\text { Czech } \\
\text { Republic }\end{array}$ & $\begin{array}{c}2 \text { months } \\
\text { (October 2013- } \\
\text { November 2013) }\end{array}$ & $\begin{array}{l}\text { Customer } \\
\text { surveys }\end{array}$ & $\begin{array}{l}\text { To determine which activities } \\
\text { are associated with customer } \\
\text { store loyalty and differential } \\
\text { effects by customer } \\
\text { socio-demographic } \\
\text { characteristics. }\end{array}$ & $\begin{array}{l}\text { Customer } \\
\text { loyalty }\end{array}$ & $\begin{array}{l}\text { - Customer loyalty is linked to low } \\
\text { prices and discount sales. } \\
-44 \% \text { of respondents said prices were } \\
\text { one of the factors that compel them to } \\
\text { make all their purchases in only one } \\
\text { supermarket chain. } \\
\text { - Probability of ranking prices and } \\
\text { sales promotions as important factors } \\
\text { was higher among older respondents } \\
\text { and respondents who spent more } \\
\text { monthly at supermarkets. }\end{array}$ \\
\hline $\begin{array}{l}\text { Caruso et al. } \\
(2018) \text { [83] }\end{array}$ & Placement & $\begin{array}{l}\text { Supermarket/ } \\
\text { grocery store }\end{array}$ & $\begin{array}{l}\text { Australia, } \\
\text { New } \\
\text { Zealand }\end{array}$ & $\begin{array}{c}56 \text { hours } \\
\text { (December } 2008 \\
\text { and December } \\
\text { 2015) } \\
\end{array}$ & $\begin{array}{c}\text { Direct } \\
\text { observation }\end{array}$ & $\begin{array}{l}\text { To assess how foot traffic and } \\
\text { visual reach of endcaps differ } \\
\text { by location. }\end{array}$ & $\begin{array}{c}\text { Foot traffic } \\
\text { Visual attention }\end{array}$ & $\begin{array}{l}\text { - Back-of-store endcaps had } 24 \% \text { more } \\
\text { foot traffic and } 30 \% \text { more visual reach } \\
\text { than front-of-store endcaps. }\end{array}$ \\
\hline $\begin{array}{l}\text { Caspi et al. } \\
\text { (2017) [84] }\end{array}$ & $\begin{array}{l}\text { Placement } \\
\text { Promotion }\end{array}$ & $\begin{array}{l}\text { Dollar store } \\
\text { Convenience } \\
\text { store } \\
\text { Other } \\
\text { (pharmacy) }\end{array}$ & US & $\begin{array}{l}5 \text { months (July } \\
\text { 2014-November } \\
\text { 2014) }\end{array}$ & $\begin{array}{l}\text { Customer } \\
\text { surveys } \\
\text { Direct } \\
\text { observation }\end{array}$ & $\begin{array}{c}\text { To examine whether customers } \\
\text { who shop at } \\
\text { small/non-traditional food } \\
\text { stores with more health } \\
\text { promotions make healthier } \\
\text { purchases. }\end{array}$ & $\begin{array}{l}\text { Healthy eating } \\
\text { index-2010 } \\
\text { (HEI) score of } \\
\text { products } \\
\text { purchased }\end{array}$ & $\begin{array}{l}\text { - Controlling for individual } \\
\text { characteristics and store type, HEI } \\
\text { scores for purchases were higher in } \\
\text { stores with greater shelf space for } \\
\text { fruits and vegetables. } \\
\text { - Healthy advertisements on the store } \\
\text { exterior were associated with lower } \\
\text { purchase HEI scores. } \\
\text { - The presence of interior healthy } \\
\text { advertisements were not associated } \\
\text { with purchase HEI scores. }\end{array}$ \\
\hline
\end{tabular}


Table 2. Cont

\begin{tabular}{|c|c|c|c|c|c|c|c|c|}
\hline Reference & $\begin{array}{l}\text { Marketing } \\
\text { Strategy }\end{array}$ & Retail Format & Country & Study Duration & Data Source & Objective & Outcome & Key Findings \\
\hline $\begin{array}{c}\text { Farrag (2012) } \\
\text { [79] }\end{array}$ & Price & $\begin{array}{l}\text { Supermarket/ } \\
\text { grocery store }\end{array}$ & Egypt & Not specified & $\begin{array}{l}\text { Interviews/focus } \\
\text { groups }\end{array}$ & $\begin{array}{l}\text { To measure to what extent } \\
\text { compliance with Shariah } \\
\text { moderates the relationship } \\
\text { between sales promotion } \\
\text { methods (price discount, } \\
\text { product sampling, buy one get } \\
\text { one free, sweepstakes/ lucky } \\
\text { draws, scratch and win offers) } \\
\text { of convenient products and } \\
\text { consumer behaviors (product } \\
\text { trial, stockpiling, spending } \\
\text { more). }\end{array}$ & $\begin{array}{l}\text { Purchase } \\
\text { attitude }\end{array}$ & $\begin{array}{l}\text { - Price discounts and buy-one-get-one } \\
\text { were associated with self-reported } \\
\text { stockpiling and spending more. } \\
\text { - Price discounts had the strongest } \\
\text { impact on consumer behavior } \\
\text { (compared to sweepstakes/ lucky } \\
\text { draw, scratch-and-win, free samples). } \\
\text { - The relationship between price } \\
\text { discounts and consumer behavior was } \\
\text { moderated by Shariah law because } \\
\text { some practices (e.g., scratch-and-win } \\
\text { and sweepstake draws) were not } \\
\text { compliant with Shariah law. }\end{array}$ \\
\hline $\begin{array}{l}\text { Felgate et al. } \\
\text { (2012) [68] }\end{array}$ & Price & $\begin{array}{l}\text { Supermarket/ } \\
\text { grocery store }\end{array}$ & UK & $\begin{array}{l}86 \text { weeks }(29 \\
\text { May 2006-21 } \\
\text { January 2008) }\end{array}$ & $\begin{array}{c}\text { Scanner/panel } \\
\text { data }\end{array}$ & $\begin{array}{l}\text { To assess how supermarket } \\
\text { loyalty card data can be used } \\
\text { to analyze the effect of price } \\
\text { promotions on spending. }\end{array}$ & $\begin{array}{l}\text { Spending by } \\
\text { product } \\
\text { subgroup }\end{array}$ & $\begin{array}{l}\text { - Promotions accounted for } 14 \% \text { of the } \\
\text { variance in sales of beef. } \\
\text { - While overall impact of promotion on } \\
\text { sales of beef was insignificant, there } \\
\text { was variability by cut of meat, } \\
\text { customer group, and price } \\
\text { promotions. }\end{array}$ \\
\hline $\begin{array}{l}\text { Fornari et al. } \\
\text { (2013) [60] }\end{array}$ & Price & $\begin{array}{l}\text { Supermarket/ } \\
\text { grocery store }\end{array}$ & Italy & 2011 & $\begin{array}{c}\text { Scanner/panel } \\
\text { data }\end{array}$ & $\begin{array}{l}\text { To assess the impact of } \\
\text { different retailing-mix levers } \\
\text { on private label market share. }\end{array}$ & $\begin{array}{l}\text { Purchase } \\
\text { volume }\end{array}$ & $\begin{array}{l}\text { - Findings suggest partial support for } \\
\text { price promotion increasing market } \\
\text { share. } \\
\text { - A significant presence on shelves, in } \\
\text { width (increase in the number of } \\
\text { product categories) and depth } \\
\text { (increase in the number of SKUs in } \\
\text { each product category) increased sales, } \\
\text { suggesting that assortment is more } \\
\text { important than price promotion. }\end{array}$ \\
\hline $\begin{array}{l}\text { Goić et al. } \\
\text { (2011) [75] }\end{array}$ & Price & $\begin{array}{l}\text { Supermarket/ } \\
\text { grocery store }\end{array}$ & US & Not specified & Not specified & $\begin{array}{c}\text { To investigate the effects of } \\
\text { cross-market promotions (e.g., } \\
\text { grocery store purchases that } \\
\text { lead to price discounts for gas) } \\
\text { on purchase volume and sales } \\
\text { price. }\end{array}$ & $\begin{array}{l}\text { Purchase } \\
\text { volume } \\
\text { Sales price }\end{array}$ & $\begin{array}{l}\text { - Offering cross-market discounts on } \\
\text { gas for grocery purchases led to an } \\
\text { increase in both price and quantity of } \\
\text { groceries purchased. }\end{array}$ \\
\hline
\end{tabular}


Table 2. Cont

\begin{tabular}{|c|c|c|c|c|c|c|c|c|}
\hline Reference & $\begin{array}{l}\text { Marketing } \\
\text { Strategy }\end{array}$ & Retail Format & Country & Study Duration & Data Source & Objective & Outcome & Key Findings \\
\hline $\begin{array}{l}\text { Guan et al. } \\
\text { (2018) [54] }\end{array}$ & Price & $\begin{array}{l}\text { Supermarket/ } \\
\text { grocery store }\end{array}$ & US & $\begin{array}{c}2 \text { years } \\
(2003-2005)\end{array}$ & $\begin{array}{l}\text { Scanner/panel } \\
\text { data }\end{array}$ & $\begin{array}{l}\text { To compare the effects of } \\
\text { individually-targeted coupons } \\
\text { for less healthful and more } \\
\text { healthful foods on consumer } \\
\text { purchasing patterns. }\end{array}$ & $\begin{array}{l}\text { Purchase } \\
\text { volume }\end{array}$ & $\begin{array}{l}\text { - Being exposed to coupons resulted in } \\
\text { an increase in the rate of purchase as } \\
\text { compared to those without coupons. } \\
\text { - People responded more to targeted } \\
\text { coupons than to untargeted coupons. } \\
\text { - Targeted coupons significantly } \\
\text { increased purchases of both healthy } \\
\text { and less healthy items, with greater } \\
\text { increases in the purchases of less } \\
\text { healthy items. }\end{array}$ \\
\hline $\begin{array}{l}\text { Hong et al. } \\
\text { (2016) [94] }\end{array}$ & Placement & $\begin{array}{l}\text { Supermarket/ } \\
\text { grocery store }\end{array}$ & UK & Not specified & $\begin{array}{l}\text { Scanner/panel } \\
\text { data } \\
\text { Direct } \\
\text { observation }\end{array}$ & $\begin{array}{l}\text { To examine whether the } \\
\text { assortment or placement of one } \\
\text { category affects purchase } \\
\text { incidence in a different } \\
\text { category that shares a common } \\
\text { display space (e.g., frozen } \\
\text { meals and ice cream). }\end{array}$ & $\begin{array}{l}\text { Purchase } \\
\text { incidence }\end{array}$ & $\begin{array}{l}\text { - Consumers were less likely to } \\
\text { purchase from a category of a given } \\
\text { assortment when it was presented } \\
\text { with another category assortment of } \\
\text { greater variety and this effect was } \\
\text { driven by the display proximity. }\end{array}$ \\
\hline $\begin{array}{l}\text { Huang et al. } \\
\text { (2012) [57] }\end{array}$ & Price & $\begin{array}{l}\text { Supermarket/ } \\
\text { grocery store }\end{array}$ & US & Not specified & $\begin{array}{l}\text { Customer } \\
\text { surveys } \\
\text { Direct } \\
\text { observation }\end{array}$ & $\begin{array}{l}\text { To identify shopper trip-level } \\
\text { and point-of-purchase-level } \\
\text { drivers of unplanned } \\
\text { consideration and purchase } \\
\text { behavior. }\end{array}$ & $\begin{array}{l}\text { Purchase } \\
\text { incidenceImpulse } \\
\text { purchases }\end{array}$ & $\begin{array}{l}\text { - An impulse purchase was more likely } \\
\text { if a shopper viewed fewer product } \\
\text { shelf displays, stood closer to the shelf, } \\
\text { and referenced external information. }\end{array}$ \\
\hline $\begin{array}{l}\text { Jamal et al. } \\
\text { (2012) [81] }\end{array}$ & Price & $\begin{array}{l}\text { Supermarket/ } \\
\text { grocery store }\end{array}$ & UK & Not specified & $\begin{array}{l}\text { Interviews/focus } \\
\text { groups }\end{array}$ & $\begin{array}{l}\text { To investigate "ethnic" } \\
\text { consumers' responses to } \\
\text { different sales promotions. }\end{array}$ & $\begin{array}{l}\text { Perceived } \\
\text { importance for } \\
\text { purchase } \\
\text { decisions }\end{array}$ & $\begin{array}{l}\text { - "Ethnic" customers reported a range } \\
\text { of responses to sales } \\
\text { promotion-some were responsive, } \\
\text { some hostile- depending on the "net } \\
\text { worth" of the sales promotion. }\end{array}$ \\
\hline $\begin{array}{l}\text { Johnson et al. } \\
\text { (2013) [58] }\end{array}$ & PlacementPrice & $\begin{array}{l}\text { Supermarket/ } \\
\text { grocery store }\end{array}$ & US & Not specified & $\begin{array}{l}\text { Scanner/panel } \\
\text { data }\end{array}$ & $\begin{array}{l}\text { To examine how customized } \\
\text { temporal discounts influence } \\
\text { consumers' decisions to } \\
\text { purchase products and overall } \\
\text { profit of the retailers. }\end{array}$ & $\begin{array}{l}\text { Purchase } \\
\text { incidence } \\
\text { Brand choice } \\
\text { Profit }\end{array}$ & $\begin{array}{l}\text { - The customization of discounts by } \\
\text { time and value yielded an increase in } \\
\text { profits of } 18-40 \% \text { relative to a model } \\
\text { that optimizes the value of the } \\
\text { discounts. }\end{array}$ \\
\hline $\begin{array}{l}\text { Kacen et al. } \\
\text { (2012) [62] }\end{array}$ & $\begin{array}{l}\text { Placement } \\
\text { Price }\end{array}$ & $\begin{array}{l}\text { Supermarket/ } \\
\text { grocery store }\end{array}$ & US & Not specified & $\begin{array}{l}\text { Customer } \\
\text { surveys }\end{array}$ & $\begin{array}{l}\text { To assess the effect of retailing } \\
\text { factors on the likelihood that a } \\
\text { consumer will make an } \\
\text { impulse purchase. }\end{array}$ & $\begin{array}{l}\text { Impulse } \\
\text { purchasing }\end{array}$ & $\begin{array}{l}\text { - Products on sale and on display in a } \\
\text { high-low pricing store increased the } \\
\text { probability of an impulse buy to } 7 \% \text {. } \\
\text { - A product had a } 13.3 \% \text { likelihood of } \\
\text { being purchased if it was not on sale } \\
\text { but a } 17.6 \% \text { likelihood if it was on sale. } \\
\text { - A product had a } 13.3 \% \text { likelihood of } \\
\text { being purchased if it was not on } \\
\text { display, but a } 20 \% \text { likelihood if it was } \\
\text { on display. }\end{array}$ \\
\hline
\end{tabular}


Table 2. Cont.

\begin{tabular}{|c|c|c|c|c|c|c|c|c|}
\hline Reference & $\begin{array}{l}\text { Marketing } \\
\text { Strategy }\end{array}$ & Retail Format & Country & Study Duration & Data Source & Objective & Outcome & Key Findings \\
\hline $\begin{array}{l}\text { Kim et al. } \\
\text { (2011) [66] }\end{array}$ & Price & Not specified & Japan & $\begin{array}{c}32 \text { years } \\
(1976-2008)\end{array}$ & $\begin{array}{l}\text { Scanner/panel } \\
\text { data } \\
\text { Marketing data }\end{array}$ & $\begin{array}{l}\text { To understand how changes } \\
\text { among manufacturers in } \\
\text { budget allocation from } \\
\text { advertising to sales promotion } \\
\text { affects sales volume and } \\
\text { profitability. }\end{array}$ & $\begin{array}{l}\text { Purchase } \\
\text { volume } \\
\text { profit }\end{array}$ & $\begin{array}{l}\text { - Expenditure on sales promotion was } \\
\text { associated with an increase in total } \\
\text { volume sales but a decrease in } \\
\text { profitability. }\end{array}$ \\
\hline $\begin{array}{l}\text { Leeflang et al. } \\
(2012) \text { [70] }\end{array}$ & Price & $\begin{array}{l}\text { Supermarket/ } \\
\text { grocery store }\end{array}$ & Spain & 1 year & $\begin{array}{c}\text { Scanner/panel } \\
\text { data }\end{array}$ & $\begin{array}{l}\text { To determine the impact of } \\
\text { price promotions in one } \\
\text { category on the revenues of } \\
\text { other categories. }\end{array}$ & $\begin{array}{l}\text { Purchase } \\
\text { volume } \\
\text { Sales revenue }\end{array}$ & $\begin{array}{l}\text { - Half of all price promotions } \\
\text { expanded revenues for that category, } \\
\text { especially for categories with deeper } \\
\text { supported discounts. } \\
\text { - There was a } 61 \% \text { probability that a } \\
\text { price promotion affected sales of at } \\
\text { least one other category. } \\
\text { - Cross-promotional effects between } \\
\text { categories more closely located in a } \\
\text { store existed. }\end{array}$ \\
\hline $\begin{array}{l}\text { Levy and } \\
\text { Gendel- } \\
\text { Guterman } \\
(2012)[98]\end{array}$ & Promotion & $\begin{array}{l}\text { Supermarket/ } \\
\text { grocery store }\end{array}$ & $\begin{array}{c}\text { Not } \\
\text { specified }\end{array}$ & Not specified & $\begin{array}{l}\text { Customer } \\
\text { surveys }\end{array}$ & $\begin{array}{l}\text { To understand how consumer } \\
\text { characteristics are correlated } \\
\text { with advertising and the } \\
\text { tendency to impulse buy store } \\
\text { brands. }\end{array}$ & $\begin{array}{l}\text { Impulse } \\
\text { purchasing }\end{array}$ & $\begin{array}{l}\text { - Advertising was positively correlated } \\
\text { to the tendency to engage in impulse } \\
\text { buying. }\end{array}$ \\
\hline $\begin{array}{l}\text { Liang et al. } \\
\text { (2017) [82] }\end{array}$ & PromotionPrice & $\begin{array}{l}\text { Other (organic } \\
\text { market) }\end{array}$ & Taiwan & 2 month (2012) & $\begin{array}{l}\text { Customer } \\
\text { surveys }\end{array}$ & $\begin{array}{l}\text { To understand organic food } \\
\text { consumers' preferences for } \\
\text { specific promotional programs } \\
\text { (e.g., discounts, giveaways, } \\
\text { limited time offers). }\end{array}$ & $\begin{array}{l}\text { Purchase } \\
\text { attitude }\end{array}$ & $\begin{array}{l}\text { - Consumers preferred the programs } \\
\text { in the discount category and the free } \\
\text { giveaway category. } \\
\text { - Limited time offers reduced purchase } \\
\text { intention. }\end{array}$ \\
\hline $\begin{array}{l}\text { Mamiya et al. } \\
\text { (2018) [71] }\end{array}$ & Price & $\begin{array}{l}\text { Supermarket/ } \\
\text { grocery store } \\
\text { Convenience } \\
\text { storeOther } \\
\text { (pharmacy) }\end{array}$ & Canada & $\begin{array}{l}6 \text { years (January } \\
2008-\text { December } \\
\text { 2013) }\end{array}$ & $\begin{array}{l}\text { Scanner/panel } \\
\text { data }\end{array}$ & $\begin{array}{l}\text { To assess whether there was a } \\
\text { differential impact of price } \\
\text { discounting of soda on sales by } \\
\text { store-neighborhood education. }\end{array}$ & $\begin{array}{l}\text { Purchase } \\
\text { volume }\end{array}$ & $\begin{array}{l}\text { - Across all levels of education and } \\
\text { types of store, discounting was } \\
\text { positively associated with soda sales. } \\
\text { - The modification of the effect of price } \\
\text { discounting by education was most } \\
\text { prominent in pharmacies, where the } \\
\text { average log sales associated with } \\
\text { discounting increased as education } \\
\text { decreased. }\end{array}$ \\
\hline
\end{tabular}


Table 2. Cont

\begin{tabular}{|c|c|c|c|c|c|c|c|c|}
\hline Reference & $\begin{array}{c}\text { Marketing } \\
\text { Strategy }\end{array}$ & Retail Format & Country & Study Duration & Data Source & Objective & Outcome & Key Findings \\
\hline $\begin{array}{l}\text { Minnema et al. } \\
(2017)[100]\end{array}$ & Promotion & $\begin{array}{l}\text { Supermarket/ } \\
\text { grocery store }\end{array}$ & Netherlands & 20 weeks (2010) & $\begin{array}{l}\text { Scanner/panel } \\
\text { data }\end{array}$ & $\begin{array}{l}\text { To examine the effectiveness of } \\
\text { instant reward programs with } \\
\text { bonus premiums (i.e., } \\
\text { collectible giveaways). }\end{array}$ & $\begin{array}{l}\text { Shopping } \\
\text { tripsCategory } \\
\text { purchase } \\
\text { incidence } \\
\text { Brand choice } \\
\text { Purchase } \\
\text { volume }\end{array}$ & $\begin{array}{l}\text { - Instant giveaway of collectible } \\
\text { premiums resulted in increased brand } \\
\text { and category choice probability, but no } \\
\text { change in purchase quantity. } \\
\text { - Consumers were more likely to } \\
\text { choose the promoted brand if it was } \\
\text { promoted with both the bonus } \\
\text { premium and price discount } \\
\text { compared to when it was promoted } \\
\text { with just a price discount. }\end{array}$ \\
\hline $\begin{array}{c}\text { Mortimer and } \\
\text { Weeks (2011) } \\
\text { [77] }\end{array}$ & Price & $\begin{array}{l}\text { Supermarket/ } \\
\text { grocery store }\end{array}$ & Australia & Not specified & $\begin{array}{c}\text { Customer } \\
\text { surveys }\end{array}$ & $\begin{array}{l}\text { To examine how price } \\
\text { information is differentially } \\
\text { considered by men and women } \\
\text { in an Australian grocery store } \\
\text { and how this affects grocery } \\
\text { shopping behavior. }\end{array}$ & $\begin{array}{l}\text { Purchase } \\
\text { attitude }\end{array}$ & $\begin{array}{l}\text { - The mean score for how consumers } \\
\text { rate the importance of promotional } \\
\text { pricing on their shopping decisions } \\
\text { was } 4.41 \text { out of } 5 . \\
\text { - Men considered price attributes of } \\
\text { products and promotional tactics as } \\
\text { being significantly lower in } \\
\text { importance than did women. }\end{array}$ \\
\hline $\begin{array}{l}\text { Mussol et al. } \\
\text { (2019) [53] }\end{array}$ & $\begin{array}{l}\text { Promotion } \\
\text { Price }\end{array}$ & $\begin{array}{l}\text { Supermarket/ } \\
\text { grocery store }\end{array}$ & France & Not specified & $\begin{array}{l}\text { Customer } \\
\text { surveys }\end{array}$ & $\begin{array}{l}\text { To explore in-store sales } \\
\text { promotions as a tool in } \\
\text { developing in-store } \\
\text { relationships with consumers. }\end{array}$ & $\begin{array}{l}\text { Purchase } \\
\text { attitude }\end{array}$ & $\begin{array}{l}\text { - Samplings, in-store games, lotteries } \\
\text { nurtured consumer loyalty and } \\
\text { relationships with brands. } \\
\text { - Price-based promotions should be } \\
\text { used to trigger purchases, whereas } \\
\text { non-monetary promotions should be } \\
\text { used to nurture brand relationships. }\end{array}$ \\
\hline $\begin{array}{l}\text { Nakamura et } \\
\text { al. (2014) [85] }\end{array}$ & Placement & $\begin{array}{l}\text { Supermarket/ } \\
\text { grocery store }\end{array}$ & UK & Not specified & $\begin{array}{l}\text { Scanner/panel } \\
\text { data }\end{array}$ & $\begin{array}{l}\text { To estimate of the effect of } \\
\text { end-of-aisle display on sales. }\end{array}$ & $\begin{array}{l}\text { Purchase } \\
\text { volume }\end{array}$ & $\begin{array}{l}\text { - End-of-aisle display increased sales } \\
\text { volumes by } 23.2 \% \text { for beer, } 33.6 \% \text { for } \\
\text { wine, and } 46.1 \% \text { for spirits, by } 51.7 \% \\
\text { for carbonated drinks, } 73.5 \% \text { for coffee, } \\
\text { and } 113.8 \% \text { for tea. } \\
\text { - The effect size was equivalent to a } \\
\text { decrease in price of between } 4 \% \text { and } \\
9 \% \text { per volume for alcohol categories, } \\
\text { and a decrease in price of between } 22 \% \\
\text { and } 62 \% \text { per volume for non-alcohol } \\
\text { categories. }\end{array}$ \\
\hline
\end{tabular}


Table 2. Cont

\begin{tabular}{|c|c|c|c|c|c|c|c|c|}
\hline Reference & $\begin{array}{c}\text { Marketing } \\
\text { Strategy }\end{array}$ & Retail Format & Country & Study Duration & Data Source & Objective & Outcome & Key Findings \\
\hline $\begin{array}{l}\text { Nakamura et } \\
\text { al. (2015) [6] }\end{array}$ & Price & $\begin{array}{l}\text { Supermarket/ } \\
\text { grocery store } \\
\text { Convenience } \\
\text { storeOther } \\
\text { (various) }\end{array}$ & UK & 1 years (2010) & $\begin{array}{l}\text { Scanner/panel } \\
\text { data }\end{array}$ & $\begin{array}{l}\text { To investigate if consumers are } \\
\text { more responsive to promotions } \\
\text { on less-healthy products; and if } \\
\text { there are socioeconomic } \\
\text { differences in food purchases in } \\
\text { response to price promotions. }\end{array}$ & $\begin{array}{l}\text { Purchase } \\
\text { volume }\end{array}$ & $\begin{array}{l}\text { - After controlling for the reference } \\
\text { price, price discount rate, and } \\
\text { brand-specific effects, the sales uplift } \\
\text { arising from price promotions was } \\
\text { larger in less-healthy than in healthier } \\
\text { categories. } \\
\text { - A } 1 \% \text { increase in the depth of price } \\
\text { discount led to a sales uplift by } 1.44 \% \\
\text { within a given category. }\end{array}$ \\
\hline $\begin{array}{l}\text { Nordfält and } \\
\text { Lange (2013) } \\
\text { [99] }\end{array}$ & Promotion & $\begin{array}{l}\text { Supermarket/ } \\
\text { grocery store }\end{array}$ & Sweden & $\begin{array}{l}2 \text { weeks (April } \\
2008 \text { and } \\
\text { March 2009) }\end{array}$ & $\begin{array}{l}\text { Scanner/Panel } \\
\text { data } \\
\text { Customer } \\
\text { surveys }\end{array}$ & $\begin{array}{l}\text { To investigate when and how } \\
\text { in-store demonstrations work } \\
\text { best. }\end{array}$ & $\begin{array}{l}\text { Purchase } \\
\text { volume }\end{array}$ & $\begin{array}{l}\text { - In-store demonstrations increased } \\
\text { sales, particularly when: closer to the } \\
\text { weekend, the product was displayed } \\
\text { next to the demonstration ( } 235.07 \% \\
\text { increase), there was personnel offering } \\
\text { the demonstration ( } 24.31 \% \text { increase), } \\
\text { there was signage promoting the } \\
\text { product }(90.76 \% \text { increase), and a } \\
\text { commercial was run on an in-store TV } \\
(36.32 \%) \text {. } \\
\text { - There was no significant change } \\
\text { when in-store demonstrations were } \\
\text { offered in a higher traffic area. }\end{array}$ \\
\hline $\begin{array}{l}\text { Osuna et al. } \\
\text { (2016) [55] }\end{array}$ & Price & $\begin{array}{l}\text { Supermarket/ } \\
\text { grocery store }\end{array}$ & $\begin{array}{c}\text { Not } \\
\text { specified }\end{array}$ & $\begin{array}{c}2 \text { years } \\
(2008-2009)\end{array}$ & $\begin{array}{l}\text { Loyalty card } \\
\text { data }\end{array}$ & $\begin{array}{l}\text { To explore how targeted } \\
\text { coupons influence the uptake } \\
\text { of new category and brand } \\
\text { purchases. }\end{array}$ & $\begin{array}{l}\text { Coupon } \\
\text { redemption } \\
\text { Product trialing }\end{array}$ & $\begin{array}{l}\text { - To entice customers to buy in new } \\
\text { categories, coupon redemption rates } \\
\text { were higher for leading brands and } \\
\text { categories that are popular, easy to } \\
\text { store, have a low number of SKUs, and } \\
\text { are frequently on sale. } \\
\text { - To increase incremental purchases, } \\
\text { coupons should be in categories that } \\
\text { have low purchase frequency and high } \\
\text { number of SKUs. }\end{array}$ \\
\hline $\begin{array}{l}\text { Page et al. } \\
\text { (2019) [86] }\end{array}$ & Placement & $\begin{array}{l}\text { Supermarket/ } \\
\text { grocery store }\end{array}$ & Australia & 24 hours & $\begin{array}{c}\text { Direct } \\
\text { observation }\end{array}$ & $\begin{array}{l}\text { To explore the shopper traffic } \\
\text { entering and exiting the } \\
\text { middle aisle, and interaction } \\
\text { with endcap promotions. }\end{array}$ & $\begin{array}{l}\text { Shopper traffic } \\
\text { Endcap use } \\
\text { Basket size }\end{array}$ & $\begin{array}{l}\text { - Overall use of endcaps in the store } \\
\text { with a middle aisle was lower than } \\
\text { that in the store with standard layout. } \\
\text { - In a standard store, } 2.2 \% \text { of all } \\
\text { observed shoppers were interacting } \\
\text { with an endcap ( } 48 \% \text { at rear, } 52 \% \text { at } \\
\text { front of store), while in the store with } \\
\text { the middle aisle, } 1.6 \% \text {, ( } 24 \% \text { at the rear, } \\
38 \% \text { at the front, and } 39 \% \text { in the } \\
\text { middle). }\end{array}$ \\
\hline
\end{tabular}


Table 2. Cont

\begin{tabular}{|c|c|c|c|c|c|c|c|c|}
\hline Reference & $\begin{array}{c}\text { Marketing } \\
\text { Strategy }\end{array}$ & Retail Format & Country & Study Duration & Data Source & Objective & Outcome & Key Findings \\
\hline $\begin{array}{c}\text { Panzone and } \\
\text { Tiffin (2012) } \\
\text { [61] }\end{array}$ & Price & $\begin{array}{l}\text { Supermarket/ } \\
\text { grocery store } \\
\text { Convenience } \\
\text { storeOther } \\
\text { (liquor store) }\end{array}$ & England & Not specified & $\begin{array}{l}\text { Customer } \\
\text { surveys } \\
\text { Receipts }\end{array}$ & $\begin{array}{l}\text { To assess the impact of price } \\
\text { promotions on wine on } \\
\text { consumer purchases }\end{array}$ & $\begin{array}{l}\text { Purchase } \\
\text { volumePurchase } \\
\text { initiation }\end{array}$ & $\begin{array}{l}\text { - The presence of a discount was } \\
\text { influential in determining what to buy } \\
\text { ( } 74 \% \text { of the total impact of the } \\
\text { discount), with a smaller effect on how } \\
\text { much of a wine to buy ( } 26 \% \text { of the } \\
\text { total impact), and no influence on } \\
\text { interpurchase time. } \\
\text { - Consumers primarily used discounts } \\
\text { to determine the segment they will } \\
\text { purchase from, and secondarily to } \\
\text { purchase multiple units of the wine } \\
\text { they had chosen. }\end{array}$ \\
\hline $\begin{array}{l}\text { Phillips et al. } \\
\text { (2015) [87] }\end{array}$ & $\begin{array}{l}\text { Placement } \\
\text { Promotion }\end{array}$ & $\begin{array}{l}\text { Supermarket/ } \\
\text { grocery store }\end{array}$ & US & 3 days & $\begin{array}{c}\text { Direct } \\
\text { observation }\end{array}$ & $\begin{array}{l}\text { To explore whether the } \\
\text { effectiveness of an end-of-aisle } \\
\text { display is weakened if there is } \\
\text { a product demonstration } \\
\text { occurring near the end-of-aisle. }\end{array}$ & Visual attention & $\begin{array}{l}\text { - The presence of an in-store } \\
\text { demonstration near the end-of-aisle } \\
\text { affected shoppers' attention paid to } \\
\text { the end-of-the-aisle. } \\
\text { - The best way to attract attention to } \\
\text { the end-of-aisle was not to have an } \\
\text { in-store demonstration near it. }\end{array}$ \\
\hline $\begin{array}{l}\text { Phipps et al. } \\
\text { (2010) [67] }\end{array}$ & Price & $\begin{array}{l}\text { Supermarket/ } \\
\text { grocery store }\end{array}$ & US & Not specified & $\begin{array}{l}\text { Scanner/panel } \\
\text { data } \\
\text { Interview/focus } \\
\text { groups }\end{array}$ & $\begin{array}{l}\text { To explore the associations of } \\
\text { discounted prices on } \\
\text { supermarket purchases of } \\
\text { selected high-calorie foods and } \\
\text { more healthful, low-calorie } \\
\text { foods. }\end{array}$ & $\begin{array}{l}\text { Purchase } \\
\text { volume } \\
\text { Purchase } \\
\text { attitude }\end{array}$ & $\begin{array}{l}\text { - Odds of purchasing on price } \\
\text { promotion compared with off } \\
\text { promotion was } 2.4 \text { for high-calorie } \\
\text { products and } 1.2 \text { for low-calorie } \\
\text { products. } \\
\text { - Odds of purchasing on sale versus } \\
\text { full price were higher for sweet snacks, } \\
\text { grain-based snacks, and } \\
\text { sugar-sweetened beverages. } \\
\text { - Participants emphasized the lure of } \\
\text { sale items and said they took } \\
\text { advantage of sales to stock up. }\end{array}$ \\
\hline $\begin{array}{l}\text { Point of } \\
\text { Purchase } \\
\text { Advertising } \\
\text { International } \\
\text { (2012) [15] }\end{array}$ & Placement & $\begin{array}{l}\text { Supermarket/ } \\
\text { grocery store }\end{array}$ & US & Not specified & $\begin{array}{l}\text { Customer } \\
\text { surveys } \\
\text { Direct } \\
\text { observation } \\
\text { Other (store } \\
\quad \text { audit) }\end{array}$ & $\begin{array}{l}\text { To investigate how shoppers } \\
\text { are interacting with the in-store } \\
\text { environment. }\end{array}$ & $\begin{array}{l}\text { Purchase } \\
\text { volume }\end{array}$ & $\begin{array}{l}\text { - More than } 1 \text { in } 6 \text { purchases were } \\
\text { made when a display with that brand } \\
\text { was present in store. }\end{array}$ \\
\hline
\end{tabular}


Table 2. Cont

\begin{tabular}{|c|c|c|c|c|c|c|c|c|}
\hline Reference & $\begin{array}{c}\text { Marketing } \\
\text { Strategy }\end{array}$ & Retail Format & Country & Study Duration & Data Source & Objective & Outcome & Key Findings \\
\hline $\begin{array}{c}\text { Pozzi (2013) } \\
{[64]}\end{array}$ & Price & $\begin{array}{l}\text { Supermarket/ } \\
\text { grocery store } \\
\text { Online retailer }\end{array}$ & US & $\begin{array}{c}2 \text { years (June } \\
\text { 2004-June 2006) }\end{array}$ & $\begin{array}{c}\text { Scanner/panel } \\
\text { data }\end{array}$ & $\begin{array}{l}\text { To assess if the introduction of } \\
\text { e-commerce affects bulk } \\
\text { purchase and stockpiling } \\
\text { behavior by customers. }\end{array}$ & $\begin{array}{l}\text { Purchase } \\
\text { volume } \\
\text { Impulse } \\
\text { purchasing }\end{array}$ & $\begin{array}{l}\text { - The share of expenditure on } \\
\text { discounted items rose by } 9-20 \% \text { with } \\
\text { the introduction of e-commerce. } \\
\text { - Online shopping did not increase the } \\
\text { likelihood of buying promoted items } \\
\text { but positively impacted the amount } \\
\text { customers bought when they bought } \\
\text { promoted items. } \\
\text { - The amount of purchasing increases } \\
\text { as the amount of discount increases. }\end{array}$ \\
\hline $\begin{array}{c}\text { Ranjan (2018) } \\
{[88]}\end{array}$ & Placement & $\begin{array}{l}\text { Supermarket/ } \\
\text { grocery store }\end{array}$ & US & $\begin{array}{c}8 \text { months } \\
\text { (1 May 2015-31 } \\
\text { December 2015) }\end{array}$ & $\begin{array}{c}\text { Scanner/panel } \\
\text { data } \\
\text { Loyalty card } \\
\text { data } \\
\text { Marketing data }\end{array}$ & $\begin{array}{l}\text { To explore how category } \\
\text { location, adjacencies, size and } \\
\text { merchandizing determine } \\
\text { consumers' category choices. }\end{array}$ & $\begin{array}{l}\text { Spending } \\
\text { Purchase } \\
\text { volume }\end{array}$ & $\begin{array}{l}\text { - Moving to a central (peripheral) } \\
\text { position in the layout improved } \\
\text { purchase quantity and purchase } \\
\text { incidence. } \\
\text { - There was an overall } \\
\text { "attention-stealing" effect of having } \\
\text { neighbors. }\end{array}$ \\
\hline $\begin{array}{l}\text { Revoredo-Giha } \\
\text { (2015) [69] }\end{array}$ & Price & $\begin{array}{l}\text { Supermarket/ } \\
\text { grocery store } \\
\text { Convenience } \\
\text { store } \\
\text { Other (various) }\end{array}$ & UK & 2006-2013 & $\begin{array}{l}\text { Scanner/panel } \\
\text { data }\end{array}$ & $\begin{array}{l}\text { To analyze the overall effect of } \\
\text { price promotions on } \\
\text { consumers' food purchases. }\end{array}$ & Spending & $\begin{array}{l}\text { - Price promotions had a positive effect } \\
\text { on total household expenditure and } \\
\text { expenditure by category across } \\
\text { socioeconomic quintiles. } \\
\text { - Consumers responded positively to } \\
\text { price promotions on fruits, vegetables, } \\
\text { soft drinks, juices, fats, and eggs. }\end{array}$ \\
\hline $\begin{array}{l}\text { Ruff et al. } \\
\text { (2016) [89] }\end{array}$ & $\begin{array}{l}\text { Placement } \\
\text { Promotion }\end{array}$ & $\begin{array}{l}\text { Convenience } \\
\text { store }\end{array}$ & US & Not specified & $\begin{array}{l}\text { Customer } \\
\text { surveys } \\
\text { Other (bag } \\
\text { check) }\end{array}$ & $\begin{array}{l}\text { To study how placement of } \\
\text { products and signs in small } \\
\text { convenience stores influence } \\
\text { shopping behavior. }\end{array}$ & $\begin{array}{l}\text { Purchase } \\
\text { incidence }\end{array}$ & $\begin{array}{l}\text { - Placement of water at eye-level and } \\
\text { of produce in at the front of the store } \\
\text { was not associated with } \\
\text { sugar-sweetened beverage purchases. } \\
\text { - Signs advertising water and } \\
\text { sugar-sweetened beverages were not } \\
\text { associated with sugar-sweetened } \\
\text { beverage purchases. }\end{array}$ \\
\hline $\begin{array}{c}\text { Sanchez-Flack } \\
\text { et al. (2017) } \\
\text { [90] }\end{array}$ & $\begin{array}{l}\text { Placement } \\
\text { Promotion }\end{array}$ & $\begin{array}{l}\text { Convenience } \\
\text { store }\end{array}$ & US & 1 years (2010) & $\begin{array}{l}\text { Customer } \\
\text { surveys } \\
\text { Other (store } \\
\text { audit) }\end{array}$ & $\begin{array}{c}\text { To examine how product } \\
\text { availability, placement, and } \\
\text { promotion were associated } \\
\text { with fruit and vegetable } \\
\text { purchasing among Hispanic } \\
\text { customers in San Diego } \\
\text { County. }\end{array}$ & $\begin{array}{l}\text { Purchase } \\
\text { volume } \\
\text { Spending }\end{array}$ & $\begin{array}{l}\text { - Each additional square foot of } \\
\text { display space dedicated to fruits and } \\
\text { vegetables and each additional fresh } \\
\text { fruits and vegetables display were } \\
\text { associated with a } \$ 0.02 \text { increase and } \\
\$ 0.29 \text { decrease, respectively, in fruit } \\
\text { and vegetable purchasing. }\end{array}$ \\
\hline
\end{tabular}


Table 2. Cont.

\begin{tabular}{|c|c|c|c|c|c|c|c|c|}
\hline Reference & $\begin{array}{l}\text { Marketing } \\
\text { Strategy }\end{array}$ & Retail Format & Country & Study Duration & Data Source & Objective & Outcome & Key Findings \\
\hline $\begin{array}{c}\text { Sano and } \\
\text { Suzuki (2013) } \\
\text { [72] }\end{array}$ & Price & $\begin{array}{l}\text { Supermarket/ } \\
\text { grocery store }\end{array}$ & Japan & $\begin{array}{l}1 \text { months (May } \\
\text { 2009-June 2009) }\end{array}$ & $\begin{array}{l}\text { Scanner/panel } \\
\text { data } \\
\text { Other (shopping } \\
\text { path) }\end{array}$ & $\begin{array}{l}\text { To determine the share of } \\
\text { product categories that should } \\
\text { be included on discount flyers. }\end{array}$ & $\begin{array}{l}\text { Purchase } \\
\text { volume }\end{array}$ & $\begin{array}{l}\text { - Price promotion of items would likely } \\
\text { increase sales, particularly in some } \\
\text { categories like drinks and western deli. } \\
\text { - Price promotion would be less } \\
\text { effective where there are already a lot } \\
\text { of discounts. }\end{array}$ \\
\hline $\begin{array}{l}\text { Seva et al. } \\
\text { (2011) [91] }\end{array}$ & Placement & $\begin{array}{l}\text { Supermarket/ } \\
\text { grocery store }\end{array}$ & Philippines & Not specified & $\begin{array}{l}\text { Customer } \\
\text { surveysDirect } \\
\text { observation }\end{array}$ & $\begin{array}{l}\text { To assess the effect of shelf } \\
\text { position and product } \\
\text { characteristics on the number } \\
\text { and duration of eye fixations } \\
\text { on a grocery shelf containing } \\
\text { junk foods. }\end{array}$ & Visual attention & $\begin{array}{l}\text { - Products placed at the top shelf } \\
\text { received the highest attention from } \\
\text { consumers as compared to the } \\
\text { products placed on the other levels } \\
\text { (the eye-level of majority of the } \\
\text { subjects was in line with the top shelf). } \\
\text { - Consumer attention decreased as the } \\
\text { products' vertical position deviated } \\
\text { from eye-level. }\end{array}$ \\
\hline $\begin{array}{c}\text { Singh (2013) } \\
\text { [73] }\end{array}$ & PromotionPrice & $\begin{array}{l}\text { Supermarket/ } \\
\text { grocery store }\end{array}$ & US & Not specified & $\begin{array}{l}\text { Scanner/panel } \\
\text { data }\end{array}$ & $\begin{array}{l}\text { To investigate how pricing and } \\
\text { promotion in frequently } \\
\text { purchased categories } \\
\text { influenced consumer visits to } \\
\text { competing multiproduct } \\
\text { grocery stores. }\end{array}$ & Store choice & $\begin{array}{l}\text { - Own-store and cross-store prices, and } \\
\text { own-store and cross-store feature } \\
\text { advertising in frequently purchased } \\
\text { categories impacted consumers' choice. } \\
\text { - For stockpiling categories, the own } \\
\text { store feature activity (but not own } \\
\text { store price) positively influenced } \\
\text { consumer choice. }\end{array}$ \\
\hline $\begin{array}{l}\text { Smithson et al. } \\
\text { (2015) [8] }\end{array}$ & Price & $\begin{array}{l}\text { Supermarket/ } \\
\text { grocery store } \\
\text { Convenience } \\
\text { store } \\
\text { Other (various) }\end{array}$ & UK & $\begin{array}{l}52 \text { weeks } \\
\text { (December } \\
\text { 2004-December } \\
\text { 2005) }\end{array}$ & $\begin{array}{l}\text { Scanner/panel } \\
\text { data }\end{array}$ & $\begin{array}{l}\text { To explore the role that price } \\
\text { promotions play in purchasing } \\
\text { levels of high-sugar food and } \\
\text { drinks. }\end{array}$ & $\begin{array}{l}\text { Purchase } \\
\text { volume } \\
\text { Brand switching }\end{array}$ & $\begin{array}{l}\text { - } 1 / 5 \text { of foods and beverages bought on } \\
\text { price promotion were purchased in } \\
\text { addition to what would be expected } \\
\text { for a given category if the price } \\
\text { promotion was not in place. } \\
\text { - Price promotions led to short-term } \\
\text { brand switching. } \\
\text { - Price promotions led to an overall } \\
\text { increase in take-home food and drink } \\
\text { volumes. }\end{array}$ \\
\hline $\begin{array}{l}\text { Spanjaard } \\
\text { (2014) [95] }\end{array}$ & Promotion & $\begin{array}{l}\text { Supermarket/ } \\
\text { grocery store }\end{array}$ & Australia & Not specified & $\begin{array}{c}\text { Customer } \\
\text { surveys } \\
\text { Direct } \\
\text { observation } \\
\text { Interviews/focus } \\
\text { groups } \\
\text { Other (diaries) }\end{array}$ & $\begin{array}{l}\text { To understand which factors } \\
\text { drive customer purchasing } \\
\text { decisions. }\end{array}$ & $\begin{array}{l}\text { Purchase } \\
\text { attitude }\end{array}$ & $\begin{array}{l}\text { - } 41 \% \text { of survey participants said they } \\
\text { were influenced by promotional offers. } \\
\text { - Trust and emotional connection the } \\
\text { brand that are main purchasing } \\
\text { decision drivers for customers. }\end{array}$ \\
\hline
\end{tabular}


Table 2. Cont.

\begin{tabular}{|c|c|c|c|c|c|c|c|c|}
\hline Reference & $\begin{array}{c}\text { Marketing } \\
\text { Strategy }\end{array}$ & Retail Format & Country & Study Duration & Data Source & Objective & Outcome & Key Findings \\
\hline $\begin{array}{c}\text { Tacka (2019) } \\
\text { [97] }\end{array}$ & Promotion & Not specified & US & $\begin{array}{c}5 \text { days }(19 \\
\text { September } \\
2018-24 \\
\text { September 2018) }\end{array}$ & $\begin{array}{l}\text { Customer } \\
\text { surveys }\end{array}$ & $\begin{array}{l}\text { To investigate the relationship } \\
\text { between marketing activities } \\
\text { (among other factors) and } \\
\text { purchases of instant } \\
\text { consumable snack foods }\end{array}$ & $\begin{array}{l}\text { Purchase } \\
\text { attitude }\end{array}$ & $\begin{array}{l}\text { - Marketing activities were rated, on } \\
\text { average, as being of "little importance" } \\
\text { or "neither important nor } \\
\text { unimportant," when purchasing an } \\
\text { instant consumable snack food. }\end{array}$ \\
\hline $\begin{array}{c}\text { Talukdar and } \\
\text { Lindsey (2013) } \\
\quad[74]\end{array}$ & Price & $\begin{array}{l}\text { Supermarket/ } \\
\text { grocery store }\end{array}$ & US & $\begin{array}{c}52 \text { weeks } \\
(2003-2004)\end{array}$ & $\begin{array}{l}\text { Scanner/panel } \\
\text { data } \\
\text { Customer } \\
\text { surveys }\end{array}$ & $\begin{array}{l}\text { To predict the effects of price } \\
\text { changes on consumers' food } \\
\text { consumption behavior. }\end{array}$ & $\begin{array}{l}\text { Purchase } \\
\text { volume }\end{array}$ & $\begin{array}{l}\text { - For healthy food, demand sensitivity } \\
\text { was greater for a price increase than } \\
\text { for a price decrease. } \\
\text { - For unhealthy food, demand } \\
\text { sensitivity was greater for a price } \\
\text { decrease than a price increase. }\end{array}$ \\
\hline $\begin{array}{l}\text { Tan et al. } \\
\text { (2018) [46] }\end{array}$ & Placement & $\begin{array}{l}\text { Supermarket/ } \\
\text { grocery store }\end{array}$ & Australia & Not specified & $\begin{array}{l}\text { Scanner/panel } \\
\text { data } \\
\text { Direct } \\
\text { observation }\end{array}$ & $\begin{array}{l}\text { To compare the sales } \\
\text { effectiveness of front versus } \\
\text { back located end-of-aisle } \\
\text { promotional displays in a } \\
\text { supermarket. }\end{array}$ & $\begin{array}{l}\text { Purchase } \\
\text { volume }\end{array}$ & $\begin{array}{l}\text { - Rear endcaps generated } 416 \% \text { sales } \\
\text { uplift while front endcaps generated } \\
346 \% \text { sales uplift. }\end{array}$ \\
\hline $\begin{array}{c}\text { Tran (2019) } \\
\text { [76] }\end{array}$ & PromotionPrice & $\begin{array}{l}\text { Supermarket/ } \\
\text { grocery store }\end{array}$ & Vietnam & 2 weeks & $\begin{array}{l}\text { Customer } \\
\text { surveys }\end{array}$ & $\begin{array}{l}\text { To investigate factors that } \\
\text { influence customers' impulse } \\
\text { purchasing behavior. }\end{array}$ & $\begin{array}{l}\text { Purchase } \\
\text { attitude }\end{array}$ & $\begin{array}{l}\text { - Sale promotion, presence of family } \\
\text { and friends, emotion, merchandise } \\
\text { display, money available and festival } \\
\text { season accounted for } 65.162 \% \text { of } \\
\text { impulse buying behavior. }\end{array}$ \\
\hline $\begin{array}{l}\text { Walmsley et al. } \\
\text { (2018) [92] }\end{array}$ & Placement & $\begin{array}{l}\text { Supermarket/ } \\
\text { grocery store }\end{array}$ & England & $\begin{array}{l}\text { 170 weeks } \\
\text { (January } \\
\text { 2012-July 2017) }\end{array}$ & $\begin{array}{l}\text { Scanner/panel } \\
\text { data }\end{array}$ & $\begin{array}{l}\text { To examine the effect of the } \\
\text { store re-arrangements on } \\
\text { purchasing of fruits and } \\
\text { vegetables. }\end{array}$ & $\begin{array}{l}\text { Purchase } \\
\text { volume } \\
\text { Spending }\end{array}$ & $\begin{array}{l}\text { - The effect of the shop re-arrangement } \\
\text { to make fruit and vegetables more } \\
\text { prominent and moving the fruit and } \\
\text { vegetable display to face the entrance } \\
\text { led to an increase in sales and total } \\
\text { dollars spent on fruits and vegetables. }\end{array}$ \\
\hline $\begin{array}{l}\text { Yildirim and } \\
\text { Aydin (2012) } \\
\text { [96] }\end{array}$ & Promotion & $\begin{array}{l}\text { Supermarket/ } \\
\text { grocery store }\end{array}$ & Turkey & 10 days & $\begin{array}{l}\text { Customer } \\
\text { surveys }\end{array}$ & $\begin{array}{l}\text { To assess the effect of } \\
\text { supermarket announcements } \\
\text { on customer behavior while } \\
\text { shopping. }\end{array}$ & $\begin{array}{l}\text { Purchase } \\
\text { attitude }\end{array}$ & $\begin{array}{l}\text { - Announcements related to price } \\
\text { discounts, buy-one-get-one offers, } \\
\text { membership deals, giveaways, and } \\
\text { coupons were most desired and } \\
\text { impactful announcements. } \\
\text { - The most noticed type of } \\
\text { announcement focused on price } \\
\text { discounts. }\end{array}$ \\
\hline $\begin{array}{c}\text { Zhang (2017) } \\
\text { [56] }\end{array}$ & Price & Online retailer & US & $\begin{array}{l}2 \text { weeks }(13 \\
\text { January 2014-26 } \\
\text { January 2014) }\end{array}$ & $\begin{array}{l}\text { Scanner/panel } \\
\text { data }\end{array}$ & $\begin{array}{l}\text { To evaluate the impact of } \\
\text { coupons and informational } \\
\text { nudges to customers identified } \\
\text { through modeling on } \\
\text { purchasing. }\end{array}$ & $\begin{array}{l}\text { Purchase } \\
\text { incidence }\end{array}$ & $\begin{array}{l}\text { - Providing information and discounts } \\
\text { to specific customers who are selected } \\
\text { through modeling led to a higher } \\
\text { conversion to purchase products. }\end{array}$ \\
\hline
\end{tabular}




\section{Discussion}

This review is the first to synthesize literature from academic and industry sources on the approaches that manufacturers use to shape retailer marketing strategies, and, in turn, consumer behavior and attitudes. More than half of the included studies focused on pricing; fewer articles assessed placement or promotion and many of these articles focused on purchase attitudes rather than behavior.

Findings suggest that all types of price promotions, including coupons, multi-buys, and TPR, shape purchasing behavior. Placement in premium store locations, such as on endcaps, and in-store samples are also effective drivers of sales. Other promotion activities, such as giveaways, games, and signs, may be less impactful. Notably, findings suggest that retailer marketing strategies may be less effective at driving sales for healthy foods and beverages $[54,67,69,74,84,89,90]$. Of the small number of studies that specifically considered sales of healthy products, the majority found that retailer marketing strategies, including signs and price promotions, were not associated with increased sales of healthy products. Two studies did find increases in healthy purchases, but effect sizes were smaller than for unhealthy products [54,69]. Previous reviews have similarly found that promotions of unhealthy products are more impactful than those for healthy products $[4,9]$. Studies of retailer- or investigator-driven interventions to specifically promote healthy purchases, however, were outside the scope of this study (these interventions are reviewed by Karpyn et al. in a paper published as part of this special issue) and may have identified retailer marketing strategies that effectively increase healthy purchases.

Findings regarding the impact of price promotions and product placement on consumer behavior are consistent with findings of previous reviews $[3,9,20,21]$. To the authors' knowledge, the review by Glanz et al. is the only study to also explore promotion; however, they did not identify any studies related to signage, and only one related to in-store sampling [21]. Several previous reviews, including Glanz et al., excluded studies in nontraditional retail settings, such as convenience and dollar stores and online retail. Findings from included studies of nontraditional retail formats suggest that retailer marketing strategies have similar effects across retail settings. One notable difference, however, is that consumers may be more likely take advantage of promotions in online retail by stockpiling, as they are not required to transport their purchases home themselves [64].

While only three studies were rated as "low quality," analytic rigor and rigor of data sources in included articles varied widely. Many articles from industry publications did not describe their analytic methods; thus, it was challenging to assess the quality of evidence of these articles. Additionally, while no studies listed conflicts of interest and many did not disclose funding sources, several were written by industry representatives and published in trade publications and may, therefore, have been more inclined to include findings that portrayed the companies favorably. A growing number of studies used store scanner and loyalty card data; these data sources, which provide large sample sizes and detailed sales information, should be used widely, particularly when paired with information on customer demographics. Several of the included studies occurred in controlled, laboratory settings; strategies that proved impactful in these settings, such as placement of products at eye-level, should be adapted and tested in real-world retail environments.

Study findings point to strategies that policymakers, public health practitioners, and retailers can use to ensure that retail environments promote healthy eating. Results suggest that policies and corporate practices that limit promotion of unhealthy products, rather than interventions to promote healthy products, may be needed to improve diet quality. Policies and practices can target each of the four TPPs identified in this study to curb promotion of unhealthy products. For example, policies could prohibit category captains from excluding competitors, or create healthy checkout aisles by prohibiting retailers from accepting stocking fees to display ultra-processed foods in checkout aisles. Considering SNAP is an important revenue stream for many US retailers, restrictions on promotion of unhealthy products could also be integrated into requirements for SNAP-authorized retailers [102]. 


\subsection{Future Research Directions}

Findings from this study highlight directions for future study. Research is needed to evaluate:

1. Online and other nontraditional retail formats. Eighty percent of included articles focused on retailer marketing strategies in grocery stores and supermarkets; other nontraditional retail formats such as dollar stores and online retailers should be assessed. Despite rapid proliferation of dollar stores in the past decade [103], they were assessed in only one of the included articles. Considering dollar stores are most common in rural and low-income communities, evaluations in dollar stores may provide insight into geographic and socioeconomic disparities in diet and food purchasing. In 2015, dollar stores represented two-thirds of new stores in designated "food deserts" [104]. Relatedly, online retail was the focus of only four of the included articles. While online grocery retail represented only $6.3 \%$ of total US grocery spending in 2019, [105] online sales are rapidly expanding, and due to concerns about COVID-19 transmission, are expected to grow more than $40 \%$ in 2020 [106].

2. Distal consumer outcomes including consumption and health. None of the included studies measured the impact of retailer marketing strategies on distal or long-term outcomes, such as diet quality or weight. Admittedly, it may be difficult to detect the impact of marketing strategies on health outcomes, especially because diet-related health outcomes are influenced by a multitude of environmental and biological factors. Dietary consumption, which has been linked to health outcomes in the public health literature, however, may be assessed. Analysis of these outcomes will require collection of different types of data, such as food frequency questionnaires or dietary recall surveys, coupled with objective purchase data. Dietary data collection methods, however, do have limitations (e.g., food frequency questionnaires may not be sensitive enough to detect small effect sizes, and dietary recalls are resource-intensive and subject to recall bias).

3. Other outcomes of importance to retailers and manufacturers. While this review excluded studies that did not measure consumer behavior or attitudes, the initial scan of titles and abstracts revealed few studies that assessed other outcomes of importance to industry, such as shortand long-term return on investment and customer lifetime value (i.e., the total profit a retailer makes from customers over their lifetime). Interventions that benefit public health, in order to be sustainable and acceptable to manufactures and retailers, must consider these outcomes.

4. Differential impacts of retail practices on consumers by demographic characteristics. Few studies compared how retailer marketing strategies affected different consumer segments, such as families with children, shoppers with low income, or shoppers who identify as racial or ethnic minorities. Insight into how certain populations may be disproportionately influenced or targeted by retailer marketing strategies can guide intervention efforts.

5. Retailer marketing strategies that have the strongest impact on consumer behavior. Only a small number of studies directly compared the impacts of different retailer marketing strategies, and most of these focused on perceived importance. Additional head-to-head comparison of retailer marketing strategies is needed to prioritize which components to include in future interventions.

6. Trade promotion practices that have the strongest impact on retailer behavior. Data on TPP are largely proprietary, and thus, research is limited on the amount manufacturers spend annually on TPP, which TPP are used most frequently, what proportion of retailer profit comes from TPP, and which TPP are the strongest drivers of retailer marketing. Additional research, potentially done in partnership with industry, is needed to understand these powerful market drivers.

\subsection{Limitations}

It is possible that different search terms or databases might have identified further studies. The quality of evidence grading tool was adapted from the Newcastle-Ottawa quality assessment 
scale, which was initially designed for case-control and cohort studies. Thus, it was challenging to assess quality of evidence for qualitative and observational studies, as well as industry reports and news articles, which provide few details on methods. Additionally, while study inclusion criteria were designed to capture studies from any country, only studies published in English were included. The majority of identified studies focused on the US and UK, and many countries were not represented in these findings. As a result, results may not be generalizable across countries and cultures.

\section{Conclusions}

This review finds evidence that by influencing retailer marketing strategies through TPP, manufacturers can shape consumer behavior and, ultimately, diets. The 74 studies included in this review suggest that TPP have a considerable effect on product placement, pricing, and promotion, and, in turn, on a range of customer outcomes, including purchase volume, spending, and attitudes. Findings point to a particularly strong relationship between price promotions and consumer behavior and differential impacts by product type and consumer characteristics. This review builds on previous work by synthesizing findings from recent studies and studies focused on non-traditional retail formats. Study findings provides valuable insight that can guide efforts by policymakers, public health practitioners, and food retailers to design retail environments that promote healthy eating. Public health practitioners and policymakers could consider policies that regulate promotion of unhealthy products by targeting each of the four TPPs identified in this study. Further investigation is warranted to determine the impact of retailer marketing on dietary outcomes and outcomes of importance to retailers. Further research is also needed in online and nontraditional retail settings.

Author Contributions: A.A.H. and C.L.P. were involved in conceptualizing this study, defining the methodology, conducting the literature search, analyzing findings, drafting and editing the manuscript, and funding acquisition. M.P., A.N.T., R.L.F. and A.J.M. were involved in conceptualizing the study, defining the methodology, and reviewing and editing the manuscript. All authors have read and agreed to the published version of the manuscript.

Funding: This research was supported by Healthy Eating Research, a national program of the Robert Wood Johnson Foundation. Training support for A.A.H. was provided through the Johns Hopkins Center for a Livable Future-Lerner Fellowship.

Acknowledgments: The authors would like to thank attendees of the January 2020 Healthy Retail Research Convening and the 2020 Healthy Eating Research Annual Meeting for their constructive feedback on research findings and conclusions. The authors would like to thank Megan Lott, Kirsten Arm and Mary Story from Healthy Eating Research for their project support.

Conflicts of Interest: The authors declare no conflict of interest. The funders commissioned research on this topic but had no role in the design of the study; in the collection, analyses, or interpretation of data; in the writing of the manuscript; or in the decision to publish the results.

\section{Appendix A}

\section{Food and Beverage Retail Formats *:}

- Supermarkets: A food retailer with greater than 9000 square feet of selling space and at least $\$ 2$ million in annual sales. Non-food sales must account for $15 \%$ or less of total store sales (e.g., Kroger, Safeway).

- Drug stores: Drug stores feature prescription-based pharmacies but generate at least $20 \%$ of their total sales from other categories, including general merchandise and food (e.g., Rite-Aid, CVS).

- Mass merchandisers: Large department stores that sell primarily general merchandise and nonperishables but also carry a limited assortment of grocery products (e.g., K-Mart, Target).

- Supercenters: Also known as hypermarkets and superstores, supercenters are hybrid stores that combine mass merchandisers with full supermarkets (e.g., Walmart Supercenter, Fred Meyer).

- Convenience and corner stores: Convenience stores typically sell gasoline, general merchandise, alcohol and tobacco, and a limited selection of staple and ready-to-eat, prepared foods (e.g., 7-Eleven, Exxon). 
- Dollar stores: Dollar stores typically emphasize low prices (many products cost $\$ 1$ ) and offer little in the way of customer service. Traditionally, they focused on staple consumer goods and other nonfood items but, have increasingly offered food (e.g., Dollar Tree, Dollar General).

- Club stores: Also referred to as warehouse or volume stores, these are large-format outlets that specialize in selling food and selected general merchandise in bulk for relatively low prices, per unit. Consumers need paid memberships to shop at them (e.g., Costco, Sam's Club).

- Online retailers: Retailers with an ecommerce presence, providing grocery click-and-collect or delivery services. These retailers can take any brick-and-mortar format (i.e., convenience stores, supermarkets, and mass merchandisers can all be online retailers).

- Other: Includes military commissaries, hospitals, and other food service providers, as well as direct-to-consumer food outlets such as farmers markets and community-supported agriculture.

* Definitions adapted from Volpe R, Kuhns A, and Jaenicke T. 2017. Store Formats and Patterns in Household Grocery Purchases, EIB-167, U.S. Department of Agriculture, Economic Research Service.

\section{Appendix B}

\section{Search Terms}

Research Question 1 Search String

((“Food" OR "Beverage")

AND ("Manufacturer *" OR "Distributor *" OR "Supplier *" OR "Processor *" OR "grower *" OR "trade association *" OR "producer *" OR "industry" OR "company")

AND ("Category captain *" OR "Category management" OR "Cooperative advertising" OR "Cooperative marketing" OR "dealer aid *" OR "fee *" OR "In-kind remuneration" OR "Pay-to-stay" OR "pouring right *" OR "Promotional allowance *" OR "Slotting" OR "Trade promotion" OR "Trade spend")

AND ("Grocer *" OR "Grocery store *" OR "Supermarket *" OR "Food store *" OR "Online grocer *" OR "Superstore *" OR "Warehouse *" OR "Club store *" OR "Convenience store *" OR "Food retailer *" OR "Food outlet *" OR "pharmac *" OR "corner store *" OR "discount store *" OR "dollar store *") NOT "pharmaceutical *"

Research Question 2 Search String

((“Food" OR "Beverage")

AND ("Manufacturer *" OR "Distributor *" OR "Supplier *" OR "Processor *" OR "grower *" OR "trade association *" OR "producer *" OR "industry" OR "company") OR ("Grocer *" OR "Grocery store *" OR "Supermarket *" OR "Food store *" OR "Online grocer * " OR "Superstore *" OR "Warehouse *" OR "Club store *" OR "Convenience store *" OR "Food retailer *" OR "Food outlet *" OR "pharmac *" OR "corner store *" OR "discount store *" OR "dollar store *"))

AND ("Category captain *" OR "Category management" OR "Cooperative advertising" OR "Cooperative marketing" OR "dealer aid *" OR "fee *" OR "In-kind remuneration" OR "Pay-to-stay" OR "pouring right *" OR "Promotional allowance *" OR "Slotting" OR "Trade promotion" OR "Trade spend" OR "Buy-one-get-one" OR "buy one get one" OR "Circular *" OR "Coupon *" OR "Cross Promotion *" OR "Discount *" OR “Display *" OR "endcap" OR "Feature and display" OR "Incentive *" OR "In-store sampl" OR "loss leader *" OR "Placement" OR "POINT-of-sale advertis *" OR "Price Promotion *" OR "Rollback *" OR "Sales Promotion *" OR "Sign *" OR "Shipper *" OR "Shelf talker *" OR "Temporary price reduction *" OR "Two-for-one" OR "two for one") AND ("Customer" OR "Shopper" OR "Consumer")

AND ("Behavior" OR "Preference" OR “Demand" OR "Consumption" OR "Choice" OR "decision"

OR "purchas *" OR "attitude *" OR "willingness to pay") NOT ("pharmaceutical *") 


\section{Appendix C}

Table A1. Newcastle-Ottawa quality scale adapted grading criteria.

\begin{tabular}{|c|c|c|c|}
\hline \multirow{4}{*}{$\begin{array}{c}\text { Selection } \\
\text { (max of } 5 \text { stars) }\end{array}$} & $\begin{array}{l}\text { (1) Representativeness of } \\
\text { the sample: }\end{array}$ & $\begin{array}{l}\text { (a) Truly representative of the average in the } \\
\text { target population }{ }^{1} \text { (e.g., all subjects or random } \\
\text { sampling) } \\
\text { (b) Somewhat representative of the average in } \\
\text { the target population }{ }^{1} \text { (e.g., nonrandom } \\
\text { sampling) } \\
\text { (c) Selected group of users } \\
\text { (d) No description of the sampling strategy }\end{array}$ & $\begin{array}{l}* \\
\text { No stars } \\
\text { No stars }\end{array}$ \\
\hline & (2) Sample size: & $\begin{array}{l}\text { (a) Justified and satisfactory } \\
\text { (b) Not justified }\end{array}$ & $\begin{array}{c}* \\
\text { No stars }\end{array}$ \\
\hline & (3) Non-respondents: & $\begin{array}{l}\text { (a) Comparability between respondents' and } \\
\text { non-respondents' characteristics is established, } \\
\text { and the response rate is satisfactory } \\
\text { (b) The response rate is unsatisfactory, or the } \\
\text { comparability between respondents and } \\
\text { non-respondents is unsatisfactory } \\
\text { (c) No description of the response rate or the } \\
\text { characteristics of the responders and the } \\
\text { non-responders } \\
\text { (d) Not applicable (e.g., aggregate sales data) }\end{array}$ & $\begin{array}{l}\text { No stars } \\
\text { NA }\end{array}$ \\
\hline & $\begin{array}{l}\text { (4) Ascertainment of risk } \\
\text { factor: }\end{array}$ & $\begin{array}{l}\text { (a) Built into dataset } \\
\text { (b) Built into study design } \\
\text { (c) Self-reported/-stated } \\
\text { (d) No information disclosed }\end{array}$ & $\begin{array}{c}* * \\
* * \\
* \\
\text { No stars }\end{array}$ \\
\hline $\begin{array}{l}\text { Comparability } \\
\text { (max of } 2 \text { stars) }\end{array}$ & $\begin{array}{l}\text { (1) The subjects in } \\
\text { different outcome groups } \\
\text { are comparable, based on } \\
\text { the study design or } \\
\text { analysis. Confounding } \\
\text { factors are controlled }\end{array}$ & $\begin{array}{l}\text { (a) The study controls for the most important } \\
\text { factor (e.g., income/SES) } \\
\text { (b) The study controls for any additional factor } \\
\text { (e.g., age, gender, household size, race) } \\
\text { (c) Not applicable (e.g., there is no comparison } \\
\text { group) }\end{array}$ & $\begin{array}{l}* \\
* \\
\text { NA }\end{array}$ \\
\hline \multirow[b]{2}{*}{$\begin{array}{c}\text { Outcome } \\
\text { (max of } 3 \text { stars) }\end{array}$} & $\begin{array}{l}\text { (1) Assessment of the } \\
\text { outcome: }\end{array}$ & $\begin{array}{l}\text { (a) Independent blind assessment } \\
\text { (b) Record linkage } \\
\text { (c) Self reports } \\
\text { (d) No description }\end{array}$ & $\begin{array}{c}* * \\
* * \\
* \\
\text { No stars }\end{array}$ \\
\hline & (2) Statistical test: & $\begin{array}{l}\text { (a) The statistical test used to analyze the data } \\
\text { is clearly described and appropriate, and the } \\
\text { measurement of the association is presented, } \\
\text { including confidence intervals and the } \\
\text { probability level (p value) } \\
\text { (b) The statistical test is not appropriate, not } \\
\text { described or incomplete }\end{array}$ & No stars \\
\hline $\begin{array}{l}\text { arget popula } \\
\text { lity scale assi } \\
\text { kimum of one } \\
\text { istical test. A }\end{array}$ & $\begin{array}{l}\text { fined based on autho } \\
\text { dies composite qualit } \\
\text { in the categories of: re } \\
\text { lum of two stars }(* *)\end{array}$ & $\begin{array}{l}\text { finition of their "target population." The Ney } \\
\text { es by awarding up to nine stars. A study car } \\
\text { ntativeness of the sample, sample size, non-re } \\
\text { e awarded in the categories of: ascertainmen }\end{array}$ & $\begin{array}{l}\text { tle-Otta } \\
\text { awardec } \\
\text { ndents, a } \\
\text { risk fac }\end{array}$ \\
\hline
\end{tabular}




\section{Appendix D}

Table A2. Quality assessment of the included studies using the Newcastle-Ottawa quality scale $(n=54)$.

\begin{tabular}{|c|c|c|c|c|c|c|c|c|}
\hline \multirow[b]{2}{*}{ Reference } & \multicolumn{4}{|c|}{ Selection } & \multirow{2}{*}{$\begin{array}{c}\text { Comparability } \\
\text { Are Confounding } \\
\text { Factors Controlled }\end{array}$} & \multicolumn{2}{|c|}{ Outcome } & \multirow[b]{2}{*}{ Overall Score } \\
\hline & $\begin{array}{l}\text { Representativeness } \\
\text { of the Sample }\end{array}$ & Sample Size & $\begin{array}{c}\text { Non- } \\
\text { Respondents }\end{array}$ & $\begin{array}{c}\text { Ascertainment } \\
\text { of Risk Factor }\end{array}$ & & $\begin{array}{l}\text { Assessment of } \\
\text { Outcome }\end{array}$ & Statistical Test & \\
\hline Andorfer et al. (2015) & 0 & 1 & 0 & 2 & 1 & 1 & 1 & $6 / 10$ \\
\hline Arce-Urriza et al. (2017) & 1 & 1 & NA & 2 & NA & 2 & 1 & $7 / 7$ \\
\hline Awan et al. (2015) & 1 & 0 & 0 & 1 & NA & 1 & 1 & $4 / 8$ \\
\hline Aziz et al. (2013) & 0 & 0 & 0 & 1 & 0 & 1 & 1 & $3 / 10 *$ \\
\hline Banks et al. (2016) & 0 & 0 & NA & 1 & NA & 1 & 0 & $2 / 7^{*}$ \\
\hline Bogomolova et al. (2019) & 1 & 1 & NA & 1 & 2 & 1 & 1 & $7 / 9$ \\
\hline Breugelmans and Campo (2016) & 1 & 1 & NA & 2 & 1 & 2 & 1 & $8 / 9$ \\
\hline Čábelková et al. (2015) & 1 & 1 & 0 & 1 & 2 & 1 & 1 & $7 / 10$ \\
\hline Huang et al. (2012) & 1 & 0 & 0 & 2 & 2 & 2 & 1 & $8 / 10$ \\
\hline Caruso et al. (2018) & 1 & 1 & 0 & 2 & 0 & 2 & 1 & $7 / 10$ \\
\hline Caspi et al. (2017) & 1 & 0 & 0 & 1 & 1 & 1 & 1 & $5 / 10$ \\
\hline Farrag (2012) & 0 & 0 & 0 & 2 & 0 & 1 & 1 & $4 / 10$ \\
\hline Felgate et al. (2012) & 1 & 1 & NA & 2 & 0 & 2 & 1 & $7 / 9$ \\
\hline Fornari et al. (2013) & 1 & 0 & NA & 2 & NA & 2 & 1 & $6 / 7$ \\
\hline Goić et al. (2011) & 0 & 0 & NA & 2 & NA & 0 & 1 & $3 / 7$ \\
\hline Guan et al. (2018) & 1 & 1 & 0 & 2 & 2 & 1 & 1 & $8 / 10$ \\
\hline Hong et al. (2016) & 1 & 1 & NA & 2 & 1 & 2 & 1 & $8 / 9$ \\
\hline Jamal et al. (2012) & 1 & 1 & 0 & 1 & NA & 1 & 0 & $4 / 8$ \\
\hline Johnson et al. (2013) & 1 & 0 & 0 & 2 & NA & 2 & 1 & $6 / 8$ \\
\hline Kacen et al. (2012) & 1 & 0 & NA & 2 & 2 & 1 & 1 & $7 / 9$ \\
\hline Kim et al. (2011) & 1 & 1 & NA & 2 & NA & 2 & 1 & $7 / 7$ \\
\hline Leeflang et al. (2012) & 0 & 0 & NA & 2 & NA & 2 & 1 & $5 / 7$ \\
\hline Levy and Gendel-Guterman (2012) & 1 & 1 & 0 & 1 & 2 & 1 & 1 & $7 / 10$ \\
\hline Liang et al. (2017) & 1 & 1 & NA & 2 & 0 & 2 & 1 & $7 / 9$ \\
\hline Mamiya et al. (2018) & 1 & 1 & NA & 2 & 2 & 2 & 1 & $9 / 9$ \\
\hline Minnema et al. (2017) & 1 & 1 & 0 & 2 & 2 & 2 & 1 & 9/10 \\
\hline Mortimer and Weeks (2011) & 1 & 1 & 0 & 2 & 1 & 1 & 1 & $7 / 10$ \\
\hline
\end{tabular}


Table A2. Cont.

\begin{tabular}{|c|c|c|c|c|c|c|c|c|}
\hline \multirow[b]{2}{*}{ Reference } & \multicolumn{4}{|c|}{ Selection } & \multirow{2}{*}{$\begin{array}{c}\text { Comparability } \\
\text { Are Confounding } \\
\text { Factors Controlled }\end{array}$} & \multicolumn{2}{|c|}{ Outcome } & \multirow[b]{2}{*}{ Overall Score * } \\
\hline & $\begin{array}{l}\text { Representativeness } \\
\text { of the Sample }\end{array}$ & Sample Size & $\begin{array}{c}\text { Non- } \\
\text { Respondents }\end{array}$ & $\begin{array}{c}\text { Ascertainment } \\
\text { of Risk Factor }\end{array}$ & & $\begin{array}{l}\text { Assessment of } \\
\text { Outcome }\end{array}$ & Statistical Test & \\
\hline Mussol et al. (2019) & 1 & 0 & 0 & 2 & 1 & 1 & 1 & $6 / 10$ \\
\hline Nakamura et al. (2015) & 1 & 1 & 0 & 2 & 1 & 2 & 1 & $8 / 10$ \\
\hline Nakamura et al. (2014) & 1 & 0 & NA & 2 & NA & 2 & 1 & $6 / 7$ \\
\hline Nordfält and Lange (2013) & 1 & 0 & NA & 2 & NA & 2 & 1 & $6 / 7$ \\
\hline Osuna et al. (2016) & 1 & 0 & NA & 2 & 1 & 2 & 1 & $7 / 9$ \\
\hline Page et al. (2019) & 1 & 0 & NA & 2 & 2 & 2 & 1 & $8 / 9$ \\
\hline Panzone and Tiffin (2012) & 1 & 1 & 0 & 1 & 0 & 1 & 1 & $5 / 10$ \\
\hline Phillips et al. (2015) & 1 & 0 & NA & 2 & 1 & 2 & 1 & $7 / 9$ \\
\hline Phipps et al (2010) & 0 & 0 & 0 & 2 & 1 & 2 & 1 & $6 / 10$ \\
\hline $\begin{array}{l}\text { Point of Purchase Advertising } \\
\text { International (2012) }\end{array}$ & 1 & 1 & 0 & 2 & 0 & 2 & 0 & $6 / 10$ \\
\hline Pozzi (2013) & 1 & 1 & NA & 2 & 2 & 2 & 1 & 9/9 \\
\hline Ranjan (2018) & 1 & 0 & NA & 2 & 1 & 2 & 1 & $7 / 9$ \\
\hline Revoredo-Giha (2015) & 1 & 1 & 0 & 2 & 1 & 2 & 1 & $8 / 10$ \\
\hline Ruff et al. (2016) & 1 & 0 & 0 & 2 & 2 & 1 & 1 & $7 / 10$ \\
\hline Sanchez-Flack et al. (2017) & 1 & 1 & 1 & 2 & 2 & 1 & 1 & $9 / 10$ \\
\hline Sano and Suzuki (2013) & 0 & 0 & NA & 2 & NA & 2 & 1 & $5 / 9$ \\
\hline Seva et al. (2011) & 0 & 0 & 0 & 2 & 0 & 2 & 1 & $5 / 10$ \\
\hline Singh (2013) & 1 & 0 & 0 & 2 & 2 & 2 & 1 & $8 / 10$ \\
\hline Smithson et al. (2015) & 1 & 1 & 0 & 2 & 2 & 2 & 1 & 9/10 \\
\hline Spanjaard (2014) & 1 & 1 & 0 & 1 & NA & 1 & NA & $4 / 7$ \\
\hline Tacka (2019) & 1 & 0 & 0 & 1 & 0 & 1 & 1 & $4 / 10$ \\
\hline Talukdar and Lindsey (2013) & 1 & 0 & NA & 2 & 2 & 2 & 1 & $8 / 9$ \\
\hline Tan et al. (2018) & 1 & 0 & NA & 2 & 1 & 2 & 1 & $7 / 9$ \\
\hline Tran (2019) & 0 & 0 & 0 & 1 & 0 & 1 & 1 & $3 / 10 *$ \\
\hline Walmsley et al. (2018) & 1 & 1 & NA & 2 & 0 & 2 & 1 & $7 / 9$ \\
\hline Yildirim and Aydin (2012) & 1 & 1 & 0 & 2 & 1 & 1 & 1 & $7 / 10$ \\
\hline Zhang (2017) & 1 & 1 & NA & 2 & 2 & 2 & 1 & 9/9 \\
\hline
\end{tabular}




\section{References}

1. Willett, W.C.; Koplan, J.P.; Nugent, R.; Dusenbury, C.; Puska, P.; Gaziano, T.A. Prevention of Chronic Disease by Means of Diet and Lifestyle Changes. In Disease Control Priorities in Developing Countries; Jamison, D.T., Breman, J.G., Measham, A.R., Alleyne, G., Claeson, M., Evans, D.B., Jha, P., Mills, A., Musgrove, P., Eds.; World Bank: Washington, DC, USA, 2006; ISBN 978-0-8213-6179-5.

2. Riesenberg, D.; Backholer, K.; Zorbas, C.; Sacks, G.; Paix, A.; Marshall, J.; Blake, M.R.; Bennett, R.; Peeters, A.; Cameron, A.J. Price Promotions by Food Category and Product Healthiness in an Australian Supermarket Chain, 2017-2018. Am. J. Public Health 2019, 109, 1434-1439. [CrossRef] [PubMed]

3. Bennett, R.; Zorbas, C.; Huse, O.; Peeters, A.; Cameron, A.J.; Sacks, G.; Backholer, K. Prevalence of healthy and unhealthy food and beverage price promotions and their potential influence on shopper purchasing behaviour: A systematic review of the literature. Obes Rev. 2019. [CrossRef] [PubMed]

4. Ravensbergen, E.A.; Waterlander, W.E.; Kroeze, W.; Steenhuis, I.H. Healthy or unhealthy on sale? A cross-sectional study on the proportion of healthy and unhealthy foods promoted through flyer advertising by supermarkets in the Netherlands. BMC Public Health 2015, 15, 470. [CrossRef] [PubMed]

5. Zorbas, C.; Gilham, B.; Boelsen-Robinson, T.; Blake, M.R.; Peeters, A.; Cameron, A.J.; Wu, J.H.; Backholer, K. The frequency and magnitude of price-promoted beverages available for sale in Australian supermarkets. Aust. N. Z. J. Public Health 2019, 43, 346-351. [CrossRef]

6. Nakamura, R.; Suhrcke, M.; Jebb, S.A.; Pechey, R.; Almiron-Roig, E.; Marteau, T.M. Price promotions on healthier compared with less healthy foods: A hierarchical regression analysis of the impact on sales and social patterning of responses to promotions in Great Britain. Am. J. Clin. Nutr. 2015, 101, 808-816. [CrossRef]

7. López, A.; Seligman, H.K. Online Grocery Store Coupons and Unhealthy Foods, United States. Prev. Chronic Dis. 2014, 11. [CrossRef]

8. Smithson, M.; Kirk, J.; Capelin, C. Sugar reduction: The evidence for action Annexe 4: An analysis of the role of price promotions on the household purchases of food and drinks high in sugar. A research project for Public Health England conducted by Kantar Worldpanel; London. 2015. Available online: https://assets.publishing.service.gov.uk/government/uploads/system/uploads/attachment_data/file/ 470175/Annexe_4._Analysis_of_price_promotions.pdf (accessed on 6 October 2020).

9. Martin, L.; Bauld, L.; Angus, K. Rapid Evidence Review: The Impact of Promotions on High Fat, Sugar and Salt (HFSS) Food and Drink on Consumer Purchasing and Consumption Behaviour and the Effectiveness of Retail Environment Interventions; NHS Health Scotland: Edinburgh, UK, 2017.

10. Hales, C.M.; Carroll, M.D.; Fryar, C.D.; Ogden, C.L. Prevalence of obesity and severe obesity among adults: United States, 2017-2018. NCHS Data Brief 2020. Available online: https://www.cdc.gov/nchs/data/ databriefs/db360-h.pdf (accessed on 6 October 2020).

11. Grier, S.A.; Kumanyika, S.K. The Context for Choice: Health Implications of Targeted Food and Beverage Marketing to African Americans. Am. J. Public Health 2008, 98, 1616-1629. [CrossRef]

12. Moran, A.J.; Musicus, A.; Findling, M.T.G.; Brissette, I.F.; Lowenfels, A.A.; Subramanian, S.; Roberto, C.A. Increases in Sugary Drink Marketing During Supplemental Nutrition Assistance Program Benefit Issuance in New York. Am. J. Prev. Med. 2018, 55, 55-62. [CrossRef]

13. Lang, T.; Heasman, M. Food Wars: The Global Battle for Mouths, Minds and Markets, 2nd ed.; Routledge Earthscan: London, UK, 2015.

14. Mancino, L.; Guthrie, J.F.; Ver Ploeg, M.; Lin, B. Nutritional Quality of Foods Acquired by Americans: Findings from USDA's National Household Food Acquisition and Purchase Survey; U.S. Department of Agriculture Economic Research Service: Washington, DC, USA, 2018.

15. 2012 Shopper Engagement Study Media Topline Report. 2012. Available online: http://ww1.prweb.com/ prfiles/2012/05/08/9489590/Media-Topline-Final.pdf (accessed on 6 October 2020).

16. Cohen, D.A.; Lesser, L.I. Obesity prevention at the point of purchase. Obes. Rev. 2016, 17, 389-396. [CrossRef]

17. Rivlin, G. Rigged: Supermarket Shelves for Sale; Center for Science in the Public Interest: Washington, DC, USA, 2016.

18. Kotler, P.; Armstrong, G. Principles of Marketing, 17th ed.; Pearson: London, UK, 2017.

19. The Path to Efficient Trade Promotions; Nielsen. 2015. Available online: https://www.nielsen.com/us/en/ insights/report/2015/the-path-to-efficient-trade-promotions/ (accessed on 6 October 2020). 
20. Backholer, K.; Sacks, G.; Cameron, A.J. Food and Beverage Price Promotions: An Untapped Policy Target for Improving Population Diets and Health. Curr. Nutr. Rep. 2019, 8, 250-255. [CrossRef]

21. Glanz, K.; Bader, M.D.M.; Iyer, S. Retail grocery store marketing strategies and obesity: An integrative review. Am. J. Prev. Med. 2012, 42, 503-512. [CrossRef] [PubMed]

22. Welch, V.; Petticrew, M.; Tugwell, P.; Moher, D.; O’Neill, J.; Waters, E.; White, H.; PRISMA-Equity Bellagio group. PRISMA-Equity 2012 extension: Reporting guidelines for systematic reviews with a focus on health equity. PLoS Med. 2012, 9. [CrossRef] [PubMed]

23. Modesti, P.A.; Reboldi, G.; Cappuccio, F.P.; Agyemang, C.; Remuzzi, G.; Rapi, S.; Perruolo, E.; Parati, G.; ESH Working Group on CV Risk in Low Resource Settings. Panethnic differences in blood pressure in Europe: A systematic review and meta-analysis. PLoS ONE 2016, 11, e0147601. [CrossRef] [PubMed]

24. Takahashi, N.; Hashizume, M. A systematic review of the influence of occupational organophosphate pesticides exposure on neurological impairment. BMJ Open 2014, 4, e004798. [CrossRef]

25. Achrol, R.S. Slotting allowances: A time series analysis of aggregate effects over three decades. J. Acad. Mark. Sci. 2012, 40, 673-694. [CrossRef]

26. Ayala, G.X.; D’Angelo, H.; Gittelsohn, J.; Horton, L.; Ribisl, K.; Sindberg, L.S.; Olson, C.; Kharmats, A.; Laska, M.N. Who is behind the stocking of energy-dense foods and beverages in small stores? The importance of food and beverage distributors. Public Health Nutr. 2017, 20, 3333-3342. [CrossRef]

27. Dhar, S.K.; Hoch, S.J.; Kumar, N. Effective category management depends on the role of the category. J. Retail. 2001, 77, 165-184. [CrossRef]

28. Efthymiou, N. Shelved Cases. Mark. Week 2003, 26, 43-44.

29. Feig, B. Notes From Orlando. Frozen Food Age 2002, 51, 18.

30. Gomez, M.I.; Maratou, L.M.; Just, D.R. Factors Affecting the Allocation of Trade Promotions in the U.S. Food Distribution System. Rev. Agric. Econ. 2007, 29, 119-140. [CrossRef]

31. Guissoni, A.; Consoli, M.; Rodrigues, J. Is Category Management in Small Supermarket Worth the Effort? Rev. Adm. Empresas 2013, 53, 592-603. [CrossRef]

32. Hamilton, S.F. Slotting Allowances as a Facilitating Practice by Food Processors in Wholesale Grocery Markets: Profitability and Welfare Effects. Am. J. Agric. Econ. 2003, 85, 797. [CrossRef]

33. Henry, J.A.; Guthrie, J.C.; McLeod, G.F.H. A Model of Supermarket Pricing Behaviour. Asian J. Bus. Res. 2015, 5, 44-57. [CrossRef]

34. Hingley, M.K. Power Imbalance in UK Agri-Food Supply Channels: Learning to Live with the Supermarkets? J. Mark. Manag. 2005, 21, 63-88. [CrossRef]

35. Hyvonen, S.; Lindblom, A.; Olkkonen, R.; Ollila, P. Exploring the effects of manufacturers' influence strategies and control on category performance in the grocery goods sector. Int. Rev. Retail Distrib. Consum. Res. 2010, 20, 311-333. [CrossRef]

36. Laska, M.N.; Sindberg, L.S.; Ayala, G.X.; D'Angelo, H.; Horton, L.A.; Ribisl, K.M.; Kharmats, A.; Olson, C.; Gittelsohn, J. Agreements between small food store retailers and their suppliers: Incentivizing unhealthy foods and beverages in four urban settings. Food Pol. 2018, 79, 324-330. [CrossRef]

37. Major, M. Charting new territory. Progress. Groc. 2005, 84, 104-108.

38. Martinelli, E.; Marchi, G. Enabling and Inhibiting Factors in Adoption of Electronic-Reverse Auctions: A Longitudinal Case Study in Grocery Retailing. Int. Rev. Retail Distrib. Consum. Res. 2007, 17, $203-218$. [CrossRef]

39. Silveira, P.D.; Marreiros, C.G. Shopper Centric Category Management in Convenience Stores: A Qualitative Study. In Proceedings of the BE-ci 2016 International Conference on Business and Economics, Selangor, Malaysia, 21-23 September 2016; pp. 327-338. Available online: https:/www.europeanproceedings.com/ files/data/article/47/1416/article_47_1416_pdf_100.pdf (accessed on 6 October 2020).

40. Stanton, J.L.; Herbst, K.C. Slotting allowances: Short-term gains and long-term negative effects on retailers and consumers. Int. J. Retail Distrib. Manag. 2006, 34, 187-197. [CrossRef]

41. Urbanski, A. Captains of your fate? Progress. Groc. 2002, 81, 28.

42. Food makers must prove their worth to the new "marketing aristocrats". Mark. News 1988, 22, $23-23$.

43. Category management is working at Giant. Chain Store Age 1997, 73, 56.

44. Managing for profits. Beverage Ind. 1997, 88, 20. 
45. Federal Trade Commission. Slotting Allowances in the Retail Grocery Industry: Selected Case Studies in Five Product Categories; 2003. Available online: https:/www.ftc.gov/sites/default/files/documents/reports/useslotting-allowances-retail-grocery-industry/slottingallowancerpt031114.pdf (accessed on 6 October 2020).

46. Tan, P.J.; Corsi, A.; Cohen, J.; Sharp, A.; Lockshin, L.; Caruso, W.; Bogomolova, S. Assessing the sales effectiveness of differently located endcaps in a supermarket. J. Retail. Consum. Serv. 2018, 43, 200-208. [CrossRef]

47. Gomez, M.I.; Rao, V.R. Market power and trade promotions in US supermarkets. Br. Food J. 2009, 111, 866-877. [CrossRef]

48. Taillie, L.S.; Ng, S.W.; Xue, Y.; Harding, M. Deal or no deal? The prevalence and nutritional quality of price promotions among U.S. food and beverage purchases. Appetite 2017, 117, 365-372. [CrossRef]

49. Price, R.K.; Livingstone, M.B.; Burns, A.A.; Furey, S.; McMahon-Beattie, U.; Holywood, L.E. What foods are Northern Ireland supermarkets promoting? A content analysis of supermarket online. Proc. Nutr. Soc. 2017, 76. [CrossRef]

50. Bogomolova, S.; Dunn, S.; Trinh, G.; Taylor, J.; Volpe, R.J. Price promotion landscape in the US and UK: Depicting retail practice to inform future research agenda. J. Retail. Consum. Serv. 2015, 25, 1-11. [CrossRef]

51. Coker, T.; Rumgay, H.; Whiteside, E.; Rosenberg, G.; Vohra, J. Paying the Price: New Evidence on the Link between Price Promotions, Purchasing of Less Healthy Food and Drink, and Overweight and Obesity in Great Britain; Cancer Research: Oxford, UK, 2019.

52. Inmar Inc 2017 Marks the Demise of Print-at-Home Coupons as Digital Redemption Climbs 67\%. Available online: https:/www.inmar.com/blog/press/2017-marks-demise-print-home-coupons-digitalredemption-climbs-67 (accessed on 8 January 2020).

53. Mussol, S.; Aurier, P.; de Lanauze, G.S. Developing in-store brand strategies and relational expression through sales promotions. J. Retail. Consum. Serv. 2019, 47, 241-250. [CrossRef]

54. Guan, X.; Atlas, S.A.; Vadiveloo, M. Targeted retail coupons influence category-level food purchases over 2-years. Int. J. Behav. Nutr. Phys. Act. 2018, 15, 111. [CrossRef]

55. Osuna, I.; González, J.; Capizzani, M. Which categories and brands to promote with targeted coupons to reward and to develop customers in supermarkets. J. Retail. 2016, 92, 236-251. [CrossRef]

56. Zhang, N. Essays on Nudging Customers' Behaviors: Evidence from Online Grocery Shopping and Crowdfunding. Ph.D. Thesis, Purdue University, West Lafayette, IN, USA, 2017.

57. Huang, Y.; Hui, S.; Inman, J.; Suher, J. Capturing the "First Moment of Truth": Understanding Point-of-Purchase Drivers of Unplanned Consideration and Purchase. Available online: https://www.msi.orghttps://www. msi.org/reports/capturing-the-first-moment-of-truth-understanding-point-of-purchase-drivers (accessed on 13 May 2020).

58. Johnson, J.; Tellis, G.J.; Ip, E.H. To Whom, When, and How Much to Discount? A Constrained Optimization of Customized Temporal Discounts. J. Retail. 2013, 89, 361-373. [CrossRef]

59. Andorfer, V.A.; Liebe, U. Do information, price, or morals influence ethical consumption? A natural field experiment and customer survey on the purchase of Fair Trade coffee. Soc. Sci. Res. 2015, 52, 330-350. [CrossRef] [PubMed]

60. Fornari, E.; Fornari, D.; Grandi, S.; Menegatti, M. The influence of retailing -mix levers on private label market share: The case of the Italian FMCG market. J. Retail. Consum. Serv. 2013, 20, 617-624. [CrossRef]

61. Panzone, L.; Tiffin, R. The Impact of Price Promotions on Producer Strategies in Markets With Large Product Heterogeneity. AGRIBUSINESS 2012, 28, 421-439. [CrossRef]

62. Kacen, J.J.; Hess, J.D.; Walker, D. Spontaneous selection: The influence of product and retailing factors on consumer impulse purchases. J. Retail. Consum. Serv. 2012, 19, 578-588. [CrossRef]

63. Breugelmans, E.; Campo, K. Cross-Channel Effects of Price Promotions: An Empirical Analysis of the Multi-Channel Grocery Retail Sector. J. Retail. 2016, 92, 333-351. [CrossRef]

64. Pozzi, A. E-commerce as a stockpiling technology: Implications for consumer savings. Int. J. Ind. Organ. 2013, 31, 677-689. [CrossRef]

65. Arce-Urriza, M.; Cebollada, J.; Fernanda Tarira, M. The effect of price promotions on consumer shopping behavior across online and offline channels: Differences between frequent and non-frequent shoppers. Inf. Syst. E-Bus. Manag. 2017, 15. [CrossRef]

66. Kim, C.; Xu, Y.; Hyde, K.F. Advertising versus Sales Promotion: An Examination of the Japanese Food Industry, 1976-2008. J. Glob. Sch. Mark. Sci. 2011, 21, 193-200. [CrossRef] 
67. Phipps, E.J.; Kumanyika, S.K.; Stites, S.D.; Singletary, S.B.; Cooblall, C.; DiSantis, K.I. Buying Food on Sale: A Mixed Methods Study With Shoppers at an Urban Supermarket, Philadelphia, Pennsylvania, 2010-2012. Prev. Chronic Dis. 2014, 11. [CrossRef] [PubMed]

68. Felgate, M.; Fearne, A.; DiFalco, S.; Martinez, M.G. Using supermarket loyalty card data to analyse the impact of promotions. Int. J. Mark. Res. 2012, 54, 221-240. [CrossRef]

69. Revoredo-Giha, C.; Akaichi, F.; Leat, P.M.K. Retailers' Promotions: What Role Do They Play in Household Food Purchases by Degree of Food Access in Scotland? Available online: https://ageconsearch.umn.edu/ record/189695 (accessed on 13 May 2020).

70. Leeflang, P.S.H.; Parreño-Selva, J. Cross-category demand effects of price promotions. J. Acad. Mark. Sci. 2012, 40, 572-586. [CrossRef] [PubMed]

71. Mamiya, H.; Moodie, E.E.M.; Ma, Y.; Buckeridge, D.L. Susceptibility to price discounting of soda by neighbourhood educational status: An ecological analysis of disparities in soda consumption using point-of-purchase transaction data in Montreal, Canada. Int. J. Epidemiol. 2018, 47, 1877-1886. [CrossRef]

72. Sano, N.; Suzuki, T. Evaluation of Discount Effects Using Poisson Regression Based on Interaction Effects Between Bargain Scale and Product Category. In Proceedings of the 2013 IEEE 13th International Conference on Data Mining Workshops; Institute of Electrical and Electronics Engineers (IEEE), Dallas, TX, USA, 7-10 December 2013; pp. 234-241.

73. Singh, S. Consumer Information Search and Choice in Retail Markets; ProQuest Information \& Learning: Cambridge, UK, 2013.

74. Talukdar, D.; Lindsey, C. To Buy or Not to Buy: Consumers' Demand Response Patterns for Healthy versus Unhealthy Food. J. Mark. 2013. [CrossRef]

75. Goic, M.; Jerath, K.; Srinivasan, K. Cross-Market Discounts. Mark. Sci. 2011, 30, 134-148. [CrossRef]

76. Tran, T.-T. Factors affecting the impulse shopping intention of Vietnamese people: An application case in Ho Chi Minh City. Int. J. Adv. Appl. Sci. 2019, 6, 65-74. [CrossRef]

77. Mortimer, G.S.; Weeks, C.S. Grocery product pricing and Australian supermarket consumers: Gender differences in perceived importance levels. Int. Rev. Retail Distrib. Consum. Res. 2011, 21, 361-373. [CrossRef]

78. Č́ábelková, I.; Pogorilyak, B.; Strielkowski, W.; Stříteský, V. Customer Store Loyalty Determinants: A Case of the Czech Republic. Dlsu Bus. Econ. Rev. 2015, 25, 28-44.

79. Farrag, D.A. Impact of Shari'ah on Consumers' Behavior Toward Sales Promotion Tools: Focus on Egyptian Convenience Products. J. Food Prod. Mark. 2017, 23, 533-552. [CrossRef]

80. Awan, H.M.; Siddiquei, A.N.; Haider, Z. Factors affecting Halal purchase intention-evidence from Pakistan's Halal food sector. Manag. Res. Rev. 2015, 38, 640-660. [CrossRef]

81. Jamal, A.; Peattie, S.; Peattie, K. Ethnic minority consumers' responses to sales promotion sinthe packaged food market. J. Retail. Consum. Serv. 2012, 19, 98-108. [CrossRef]

82. Liang, A.R.-D.; Yang, W.; Chen, D.-J.; Chung, Y.-F. The effect of sales promotions on consumers' organic food response An application of logistic regression model. Br. Food J. 2017, 119, 1247-1262. [CrossRef]

83. Caruso, W.; Corsi, A.M.; Bogomolova, S.; Cohen, J.; Sharp, A.; Lockshin, L.; Tan, P.J. The Real Estate Value Of Supermarket Endcaps Why Location In-Store Matters. J. Advert. Res. 2018, 58, 177-188. [CrossRef]

84. Caspi, C.E.; Lenk, K.; Pelletier, J.E.; Barnes, T.L.; Harnack, L.; Erickson, D.J.; Laska, M.N. Association between store food environment and customer purchases in small grocery stores, gas-marts, pharmacies and dollar stores. Int. J. Behav. Nutr. Phys. Act. 2017, 14. [CrossRef]

85. Nakamura, R.; Pechey, R.; Suhrcke, M.; Jebb, S.A.; Marteau, T.M. Sales impact of displaying alcoholic and non-alcoholic beverages in end-of-aisle locations: An observational study. Soc. Sci. Med. 2014, 108, 68-73. [CrossRef]

86. Page, B.; Trinh, G.; Bogomolova, S. Comparing two supermarket layouts: The effect of a middle aisle on basket size, spend, trip duration and endcap use. J. Retail. Consum. Serv. 2019, 47, 49-56. [CrossRef]

87. Phillips, M.; Parsons, A.G.; Wilkinson, H.J.; Ballantine, P.W. Competing for attention with in-store promotions. J. Retail. Consum. Serv. 2015, 26, 141-146. [CrossRef]

88. Ranjan, B. Studying Shopping Decisions and Layout Planning in Physical Retail Settings; ProQuest Information \& Learning: Cambridge, UK, 2018.

89. Ruff, R.R.; Akhund, A.; Adjoian, T. Small Convenience Stores and the Local Food Environment: An Analysis of Resident Shopping Behavior Using Multilevel Modeling. Am. J. Health Promot. 2016, 30, 172-180. [CrossRef] 
90. Sanchez-Flack, J.; Pickrel, J.L.; Belch, G.; Lin, S.-F.; Anderson, C.A.M.; Martinez, M.E.; Arredondo, E.M.; Ayala, G.X. Examination of the Relationship between In-Store Environmental Factors and Fruit and Vegetable Purchasing among Hispanics. Int. J. Env. Res. Public Health 2017, 14. [CrossRef]

91. Seva, R.R.; Go, K.; Garcia, K.; Grindulo, W. Predictive Model of Attention in Viewing Selected Grocery Products. Dlsu Bus. Econ. Rev. 2011, 21, 97-110.

92. Walmsley, R.; Jenkinson, D.; Saunders, I.; Howard, T.; Oyebode, O. Choice architecture modifies fruit and vegetable purchasing in a university campus grocery store: Time series modelling of a natural experiment. BMC Public Health 2018, 18, 1149. [CrossRef] [PubMed]

93. Banks, S. Tap into the treat trends. Conv. Store 2016, 57-60.

94. Hong, S.; Misra, K.; Vilcassim, N. The Perils of Category Management: The Effect of Product Assortment on Multicategory Purchase Incidence. J. Mark. 2016, 80, 34-52. [CrossRef]

95. Spanjaard, D.; Young, L.; Freeman, L. Emotions in supermarket brand choice: A multi-method approach. Qual. Mark. Res. Int. J. 2014, 17, 209-224. [CrossRef]

96. Yildirim, Y.; Aydin, O. Investigation of the effects of discount announcements on consumers' purchase decisions: A case study in supermarket. Procedia Soc. Behav. Sci. 2012, 62, 1235-1244. [CrossRef]

97. Tacka, R.C. Consumer Impulsivity and Attitude: A Quantitative study of Instant Consumable Snack Food Purchases; ProQuest Information \& Learning: Cambridge, UK, 2019.

98. Levy, S.; Gendel-Guterman, H. Does advertising matter to store brand purchase intention? A conceptual framework. J. Prod. Brand Manag. St. Barbar. 2012, 21, 89-97. [CrossRef]

99. Nordfält, J.; Lange, F. In-store demonstrations as a promotion tool. J. Retail. Consum. Serv. 2013, 20, 20-25. [CrossRef]

100. Minnema, A.; Bijmolt, T.H.A.; Non, M.C. The impact of instant reward programs and bonus premiums on consumer purchase behavior. Int. J. Res. Mark. 2017, 34, 194-211. [CrossRef]

101. Aziz, Y.; Chok, N. The Role of Halal Awareness, Halal Certification, and Marketing Components in Determining Halal Purchase Intention Among Non-Muslims in Malaysia: A Structural Equation Modeling Approach:: Vol 25, No 1. J. Int. Food Agribus. Mark. 2012, 25. [CrossRef]

102. United States Department of Agriculture SNAP Retailer Data: 2019 Year End Summary; 2019. Available online: https://fns-prod.azureedge.net/sites/default/files/resource-files/2019-SNAP-RetailerManagement-Year-End-Summary.pdf (accessed on 18 May 2020).

103. Donahue, M.; Mitchell, S. Dollar Stores Are Targeting Struggling Urban Neighborhoods and Small Towns. One Community Is Showing How to Fight Back; Institute for Local Self-Reliance: Washington, DC, USA, 2018. Available online: https://ilsr.org/dollar-stores-target-cities-towns-one-fights-back/ (accessed on 6 October 2020).

104. Dollar Stores Are Taking Over the Grocery Business, and It's Bad News for Public Health and Local Economies. Available online: https://civileats.com/2018/12/17/dollar-stores-are-taking-over-the-grocerybusiness-and-its-bad-news-for-public-health-and-local-economies/ (accessed on 18 May 2020).

105. 2019 Ecommerce in Review: U.S. Online Grocery Sales. Available online: https:/www.digitalcommerce360. com/2019/12/24/2019-ecommerce-in-review-online-grocery-sales/ (accessed on 18 May 2020).

106. Redman, R. Online Grocery Sales to Grow 40\% in 2020. Available online: https://www.supermarketnews. com/online-retail/online-grocery-sales-grow-40-2020 (accessed on 18 May 2020).

(C) 2020 by the authors. Licensee MDPI, Basel, Switzerland. This article is an open access article distributed under the terms and conditions of the Creative Commons Attribution (CC BY) license (http://creativecommons.org/licenses/by/4.0/). 